\title{
GEM WEALTH OF TANZANIA
}

By Dona M. Dirlam, Elise B. Misiorowski, Rosemary Tozer;

Karen B. Stark, and Allen M. Bassett

The East African nation of Tanzania has great gem wealth. First known by Westerners for its diamonds, Tanzania emerged in the 1960s as a producer of a great variety of other gems such as tanzanite, ruby, fancycolored sapphire, garnet, and tourmaline; to date, more than $50 \mathrm{gem}$ species and varieties have been produced. As the 1990s begin, De Beers has reinstated diamond exploration in Tanzania, new gem materials such as transparent green zoisite have appeared on the market, and there is increasing interest in Tanzania's lesserknown gems such as scapolite, spinel, and zircon. This overview describes the main gems and gem resources of Tanzania, and reviews their history, geology, mining, and economic development.

\section{ABOUT THE AUTHORS}

Ms. Dirtam is senior librarian, and Ms. Misiorowski, Ms. Tozer, and Ms. Stark are research librarians, at the Liddicoat Gemological Library and Information Center of the Gemological institute of America, Santa Monica, California. Dr. Bassett is chief geologisUgemologist of Tan-Minerals Mining Co., Ltd., AlCC, Box 8301, Arusha, Tanzania.

Acknowiedgments: The authors are grateful for the valuable contributions by Dr. N. Barot, Edward Boehm, Campbell Bridges, Jo Ellen Cole, Patricia Gray, Dr. A. J. A. (Bram) Janse, Jonte Berlon, Holly Kane, Dr. P. Keller, Cheryl Kremkow, Dr. H. Krupp, Dr. A. Levinson, Dr. E. Malisa, Roland Nafule, Ruth Patchick, Dr. J. Saul, Rogers Sezinga, Abe Suleman, TOFCO, Tsavo Madini, and Alli S. Zullu.

Gerns \& Gemology, Vol. 28, No. 2, pp. 80-102. (C) 1992 Gemological Institute of America

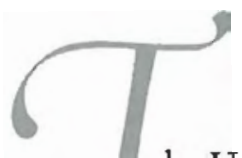

he United Republic of Tanzania, the largest of the East African countries, is composed of mainland Tanzania and the island of Zanzibar. It is regarded by many as the birthplace of the earliest ancestors of Homo sapiens. To the gem industry, however, Tanzania is one of the most promising frontiers, with 50 gem species and varieties identified, to date, from more than 200 occurrences.

"Modern" mining started in the gold fields of Tanzania in the late 1890s (Ngunangwa, 1982), but modern diamond mining did not start until 1925, and nearly all mining of colored stones has taken place since 1950. Even so, only a few of the gem materials identified have been exploited to any significant extent: diamond, ruby, sapphire, purplish blue zoisite (tanzanite; figure 1), and green grossular (tsavorite) and other garnets. Relatively minor amounts of tourmaline, emerald, aquamarine, alexandrite, amethyst, scapolite, spinel, and other gem materials have also been mined (see figure 2). Recently, the Tanzanian govemment and the world's mining industry have begun to reinvestigate the potential for large-scale gem production, spurred by changing political, technological, and economic factors both in Tanzania and worldwide. For example, a consortium headed by the World Bank has approved a loan package of $\$ 1.8$ billion for renovation of the nation's infrastructure ("Tanzania's latent opportunities," 1992). Tanzania seems poised on the edge of fully developing its rich gem resources.

This article will first briefly review the history, geology, and mining of Tanzania. We will then examine each of the major gem materials and their occurrences.

\section{HISTORY}

Hominid habitation in this part of East Africa has been documented back to about 6 million years (members of the Leakey family were the first to establish the anthropological importance of Olduvai Gorge). The ancient Greeks knew of Tanzania, which they called Azania. The Bantu people, who 
Figure 1. Tanzania is perhaps best known for the transparent purplish blue variety of zoisite, tanzanite, which was discovered in the 1960s and named by Tiffany et Co. in honor of its country of origin. The tanzanite in this pendant weighs $96.42 \mathrm{ct}$; the earrings weigh a total of 24.29 ct. Jewelry courtesy of Tiffany e Co.

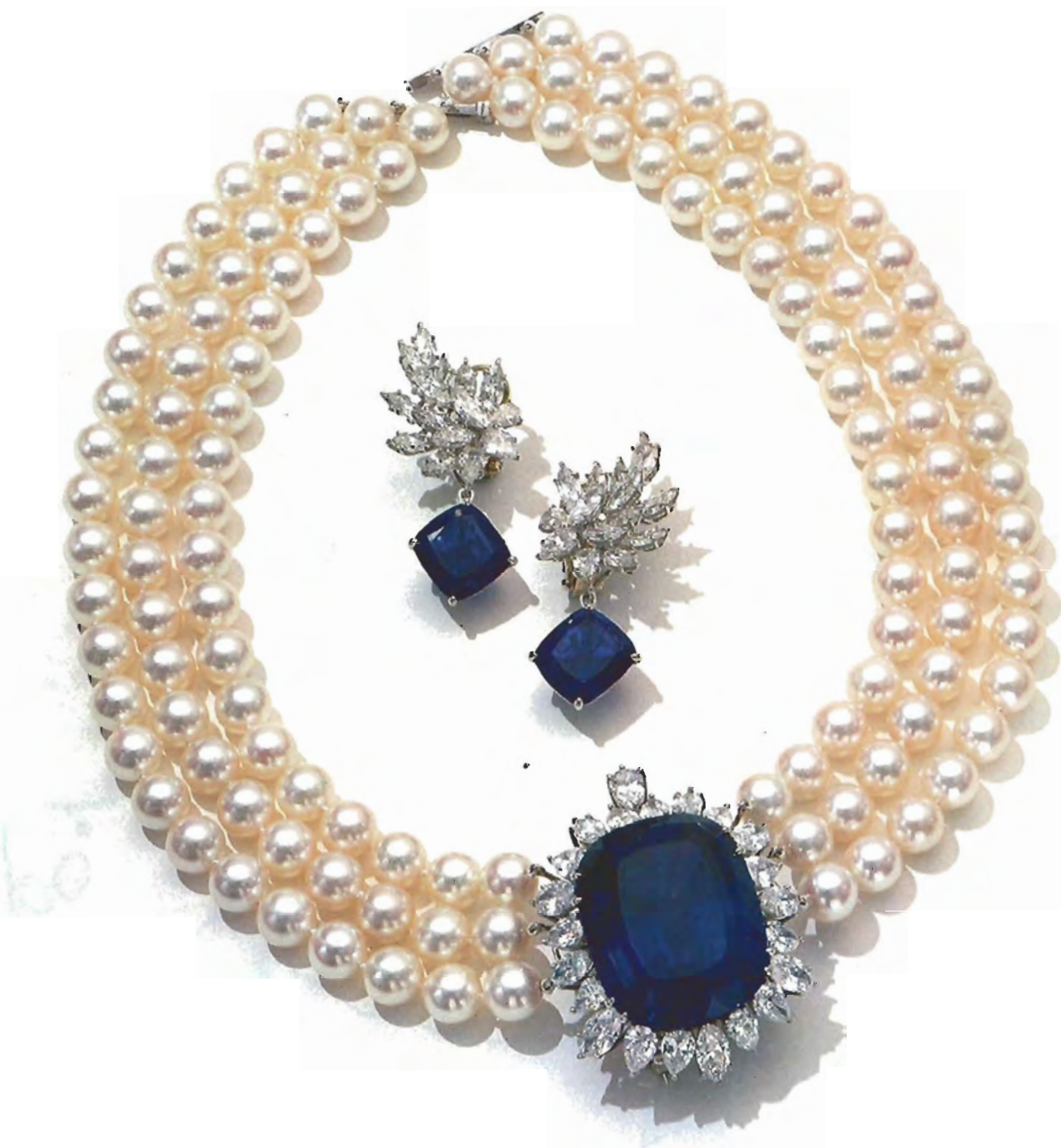

currently make up the majority of Tanzania's population of 26 million, apparently arrived in the region in the 1st century A.D. (Vidal-Naquet, 1987). Because of its strategic location, Tanzania has been a major trading center since the 9th century. About this time, the coastal regions were settled by Moslems from Arabia, Persia (now Iran), and elsewhere, who worked with the Swahili, a people of the eastern division of the Bantu. Together, they established trading centers such as Malindi, Mombasa, and Kilwa. The last, in southern Tanzania, controlled one of the ancient gold routes into the interior and later became the trading center for ivory, rock crystal (quartz), and slaves, as well as gold (Horton, 1987).
Portugal established control over the area in the early 1500 s, but it was displaced by Great Britain in the 1600s. Then, in the 19th century, Germany gained control of the mainland, through treaties signed with inland chiefs, and established the German East Africa protectorate; following World War I, this became Tanganyika, under British mandate. Tanganyika gained independence from Great Britain in 1961 and three years later united with Zanzibar, a British protectorate since 1890, to form the United Republic of Tanzania. (Throughout this article we use the term Tanzania even though the country may have been known by another name at the time of the specific event being discussed. For example, when diamonds 


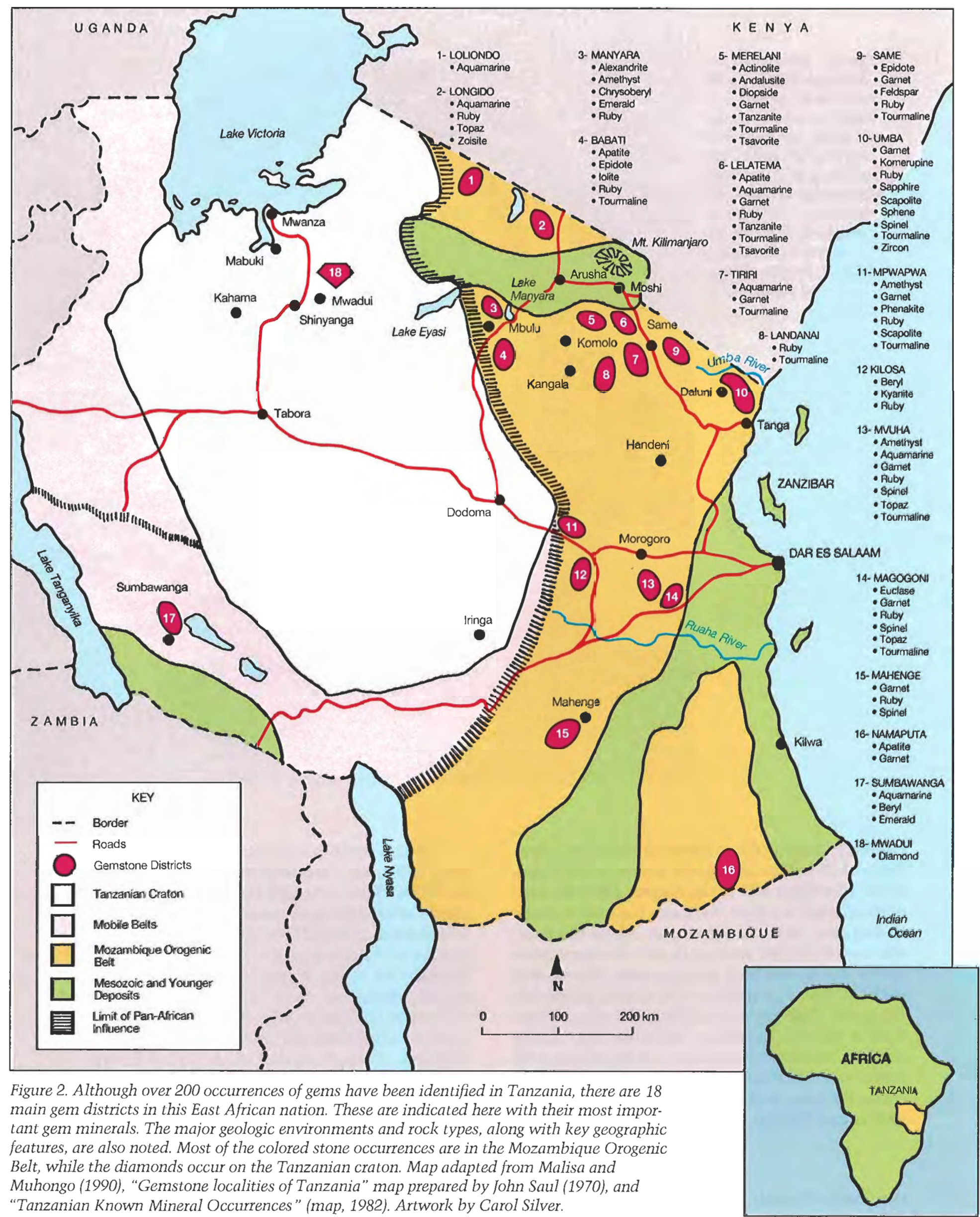


were first found, the country was known as German East Africa. Also, for the purposes of this discussion, Tanzania will refer exclusively to the mainland portion of the nation.)

Until the late 1960s, gem mining in Tanzania was done primarily by individuals and private companies. In 1971, however, the government nationalized the first mines and established Tanzania Gemstone Industries (TGI), under the National Development Corp., to oversee them (Rwezaura, 1990). In 1972, the government created the State Mining Corp. (STAMICO), with TGI as its subsidiary. Because overall gem production was so poor during this period, in 1976 STAMICO began geologic as well as mining studies in an effort to improve the situation.

During most of the 1970s and into the 1980s, the government required that all mining be controlled by the state. All gem rough had to be bought through STAMICO and sold on the open market. Although foreign companies were discouraged from engaging in mining activity for many years, selective foreign investment has been allowed since the early 1980s. In 1985, the newly enacted Economic Recovery Program established provisions favorable to foreign investment (Notholt, 1990). Today, the government is issuing gemstone prospecting, mining, and "master dealer" licenses under which private individuals may prospect, mine, trade, and export gem minerals |"ICA presents ...," 1991), as well as offering important economic incentives.

\section{REGIONAL GEOLOGY}

East Africa has been the subject of formal geologic mapping and exploration projects since the late 1800s. Several major geologic environments have been identified: an Archean craton, orogenic mobile belts, coastal marine sedimentary deposits, rift valleys of various ages, recent (Tertiary) volcanism, and various types of surface deposits. Several of these environments contain gem occurrences.

The main geologic divisions in Tanzania (again, see figure 2) are: on the west, the Tanzanian craton, which is of Archean age (2,500-3,000 My [million years]); and, on the east, the Mozambique Orogenic Belt $(1,200-450 \mathrm{My})$. A craton is an ancient, stable part of a continent that is composed of igneous and metamorphic rocks (see, e.g., Janse, 1992; Kirkley et al., 1991). The Tanzanian craton is surrounded by Middle-to-Late Proterozoic (1,600-800 My) mobile belts, which are long, narrow crustal regions subjected to geologic forces that resulted in processes such as folding and mountain building. These belts include the Ubendian to the southwest, the Karagwe-Ankolean to the northwest, and the Usagaran to the east.

The Usagaran is the Tanzanian portion of the much larger Mozambique Orogenic Belt (orogenic belts are those that were mobile during their formative stages|, which extends under most of East Africa. It is about $250 \mathrm{~km}$ wide and runs for about $5,000 \mathrm{~km}$ from Madagascar and Mozambique in the south to Ethiopia and Sudan in the north. The rocks in this belt have undergone extensive metamorphism, plutonism, folding, and faulting. This belt has a complex history of several cycles of tectonism (major crustal movements) and at least three stages of regional and contact metamorphism, starting in the Late Proterozoic $(1,200 \mathrm{My})$. These include high-grade metamorphic events that produced several granulite complexes (sets of metamorphic mineral assemblages resulting from high pressures and high temperatures, $650^{\circ}-800^{\circ} \mathrm{C}$ ). The latest thermal events were caused by the Pan-African Orogeny (800-450 My). East of the Mozambique Belt lies the coastal plain of Tanzania, which is underlain by Mesozoic (225-65 My) and more recent sediments.

The formation of granulites in association with major tectonic events is particularly important, because a wide range of minerals were subjected to heat, pressure, and hot fluids. During such geologic processes, not only are new minerals formed, but chromophores such as chromium and vanadium may also be remobilized from their original mineral hosts. Under favorable conditions, this results in the formation of gem crystals of unusual colors and phenomena, such as "chrome" tourmalines and change-of-color garnets and sapphires (figure 3). Malisa and Muhongo (1990) outlined 17 major occurrences of granulite-type rocks and identified the eastern granulite complexes in the Mozambique Belt as having the greatest potential for gem materials (again, see figure 2).

\section{MINING}

Exploration and Techniques. Until recently, most exploration in Tanzania was based on prospecting using visual observation. In fact, major deposits have been found by local herdsmen familiar with gems (Key and Ochieng, 1991a). Traditionally, mining has been carried out with minimal mechanization. Most of the miners are itinerant laborers who work sporadically, depending on the climatic and political conditions. For example, mining is generally hampered 

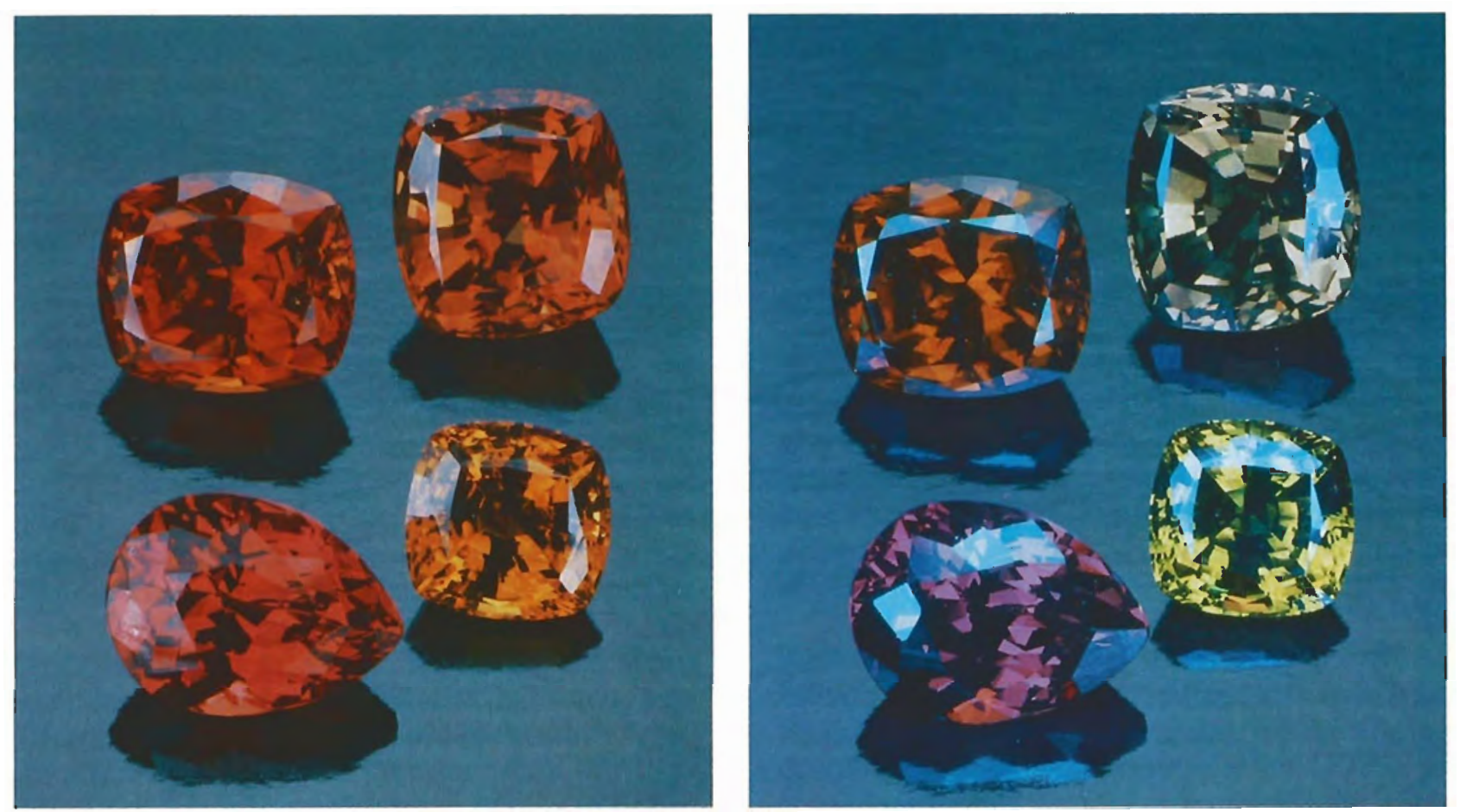

Figure 3. Tanzania is particularly noted for its production of unusual gem materials, like these color-change garnets seen here in incandescent (left) and fluorescent (right) illumination. The stones range from 3.89 to $1.57 \mathrm{ct}$. Photo (C) GIA and Tino Hammid.

from December to May, the wettest months of the year. Furthermore, miners sometimes leave one mining area for another that has just opened up or expanded, resulting in the temporary abandonment of the first mine.

The only consistently large-scale gem-mining operation in Tanzania has been at the Mwadui (Williamson) diamond mine. For a time in the 1960s, there were also large-scale operations at the Umba River deposits, but mechanization declined with the onset of nationalization. Although there are some operations that use heavy equipment, most gem mining in Tanzania today is small scale. The deposits mined may be either primary in the host rock or secondary (which includes both alluvial along rivers, or eluvial in the weathered zones above and/or adjacent to the primary deposits). Details relating to the type of mining associated with a particular deposit are provided below in the discussions of specific gem materials.

Small-scale mining in Tanzania-whether by private individuals, mining organizations, or private companies-is labor intensive. For example, in alluvial deposits along rivers such as the Umba and the Lukande, miners shovel gem-bearing gravels onto screens and wash them in nearby stream waters (figure 4). In primary deposits like the emerald occur- rence at Lake Manyara, low-energy explosives are used to break up the rock and then the material is sorted by hand. Only recently have backhoes and mechanized shaker tables again been brought into some of the more accessible mining areas. Today, modern equipment is found at the Mwadui diamond mine, in some corundum-mining areas (figure 5), and in portions of the Merelani Hills tanzanite area.

It is appropriate to mention here how difficult it can be to ascertain the actual source for most gems. In East Africa, in particular, many gems mined in Tanzania are carried across the border into neighboring Kenya and especially to its cosmopolitan cities Nairobi and Mombasa. Consequently, gems from this area are commonly described simply as coming from East Africa rather than specifically from Tanzania. Even when specific sources are given by the seller, one cannot always depend on the accuracy of the information. An improvement in the reporting of localities is evident in the recent literature (see, e.g., Malisa and Muhongo, 1990; Key and Ochieng, 1991a). Still, we have taken this factor into consideration when evaluating information about specific gem materials.

Environmental and Health Concerns. The problems that face resource-rich but economically poor Tan- 


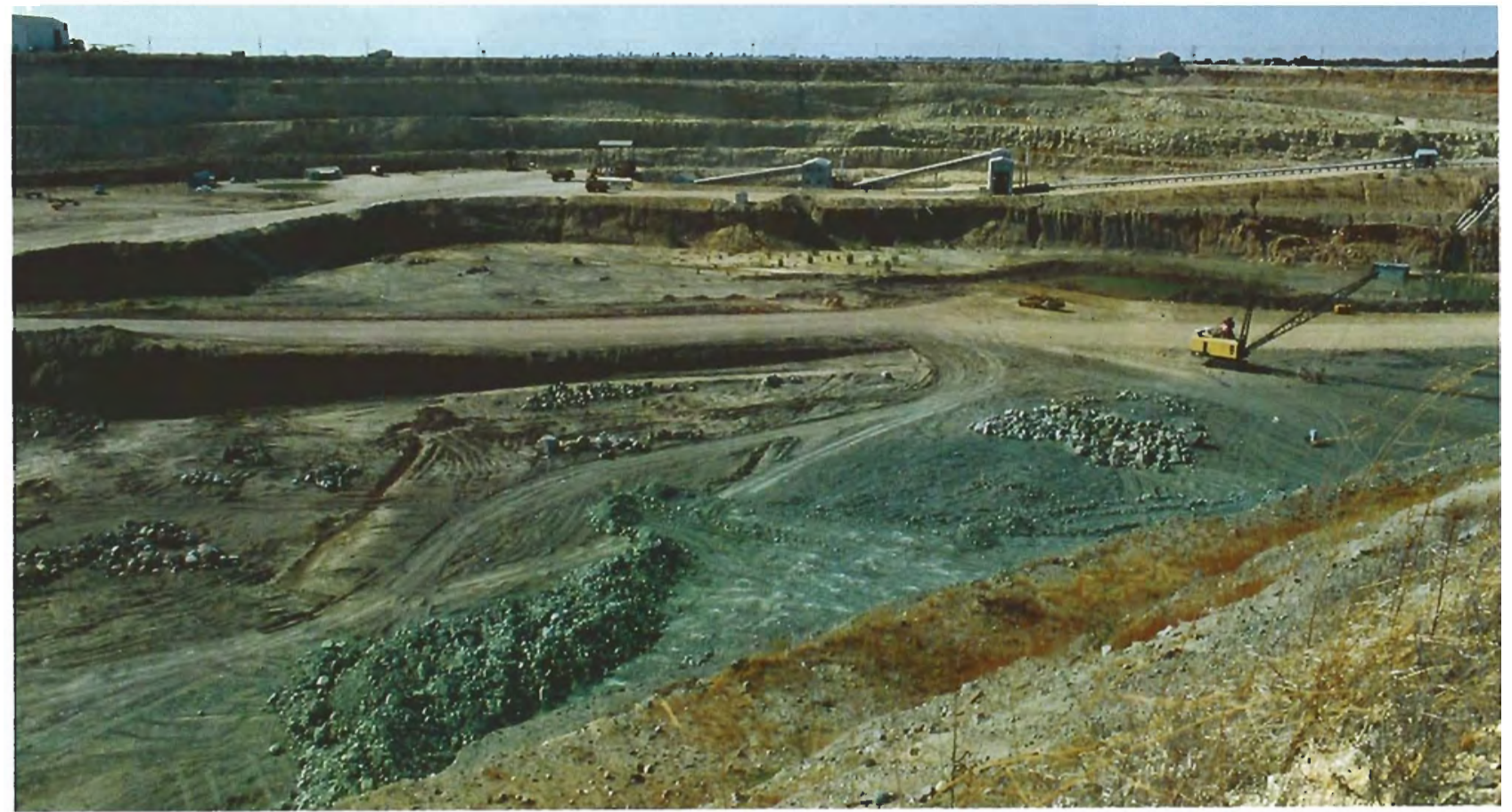

Figure 6. The Mwadui diamond mine, in northern Tanzania, is currently the largest, most sophisticated mining operation in Tanzania. The kimberlite pipe at Mwadui is about four times the size of the Premier mine. Photo courtesy of the Central Selling Organisation.

ically feasible ("Tanzania's latent opportunities," 1992). At present, the only active diamond mine is the Mwadui, also known as the Williamson mine, in northern Tanzania (figure 6). Although diamonds were found at Mabuki as early as 1910, mining did not begin there until after 1925 (B. Janse, pers. comm., 1992). Mabuki and two other small mines, at Kisumbe and Nzega, were operated by the Tanganyika Diamond and Gold Development Company until mining was halted in 1938. One of their geologists, Dr. John $\mathrm{T}$. Williamson, continued to search independently in the area. In 1940, on the verge of bankruptcy, he discovered at Mwadui what would prove to be the world's largest (in surface area) kimberlite pipe: 146 hectares, about four times the size of South Africa's Premier mine (Gobba, 1991). Dr. Williamson subsequently developed the mine, now called the Mwadui, into one of the richest in Africa. It is unusual for a primary deposit, in that about half of the diamonds mined there are of gem quality (Balfour, 1987).

After Williamson died in 1958, De Beers and the national government jointly purchased the mine from his heirs. Although the mine was officially nationalized in the 1960s, ownership actually passed to a Bermuda-based holding company, Willcroft, a subsidiary of De Beers in which Tanzania took a 50\% share. Reports in the literature suggest that the mine is nearly played out: Whereas $924,000 \mathrm{ct}$ of diamond were produced from 3.3 million tons of ore in 1966, the same amount of ore produced only $265,600 \mathrm{ct}$ in 1984 ("Background analysis-Tanzania ...," 1986).

Two kimberlites found in the Kahama area west of Mwadui were mined briefly during the late 1960s, but they are not currently being worked (Janse, 1991).

Geology. The Tanzanian diamond deposits have certain characteristics that make them unique. The most notable feature is that they occur in kimberlite crater deposits or in closely associated weathered gravels, as well as in the kimberlite pipe itself. Elsewhere in the world, kimberlite crater deposits (by definition, on the surface) normally have been removed by erosion. For example, kimberlites that occur on Precambrian shields (outcropping Archean cratons) have usually been eroded down to their roots and, thus, crop out in the form of small dikes or irregular-shaped pipes. However, the Mwadui kimberlite outcrop is a large $(1600 \times 1100 \mathrm{~m})$ ellipsoidal crater that is as much as $360 \mathrm{~m}$ deep. The diamond deposits are associated with shaley sediments deposited in a crater lake, with breccias derived from a mixture of kimberlite and disintegrated gneiss bedrock, and with gravels derived from these two components and from the overlying calcrete. Because the kimberlite intrusions in Tanzania are relatively young (45-55 $\mathrm{My}$, as compared to 90-120 My for most of the South African pipes), they have not been subjected to the extensive erosion experienced by their older counterparts. Consequently, secondary deposits are minimal.

Although Tanzania is literally peppered with kimberlites, many of them are barren of diamonds. Of those 44 that are diamondiferous, only a few are economically viable and these are all found in a belt on the craton (B. Janse, pers. comm., 1992). 
Description of the Material. In addition to its high percentage of gem-quality near-colorless diamonds, the Mwadui mine is also known for producing pink (figure 7) and green diamonds. In 1954, for example, the Mwadui mine produced 105 ct of bright pink diamonds for every 100 tons of ore mined ("Background analysis ...." 1986). The only reported properties for Tanzanian diamonds (from Mwadui) are consistent with those reported for diamonds from other localities (Tsai et al., 1979).

Current Production and Future Potential. Tanzania has produced 18 million carats of diamonds since the end of World War I. More than 90\% of these came from the Mwadui pipe ("Tanzania's latent opportunities," 1992), with most of the remainder coming from the adjacent Alamasi mine. After reaching a peak of $926,758 \mathrm{ct}$ in 1967, production at the Mwadui mine has declined to between 150,000 and 200,000 ct annually in recent years (Wilson, 1971; Notholt, 1990). The Mwadui deposit has yielded several diamonds over $100 \mathrm{ct}$; the largest piece of rough on record weighed $256 \mathrm{ct}$. Williamson presented the largest recorded:Tanzanian pink diamond-54 ct in the rough-as a wedding present to then-Princess Elizabeth of Great Britain in 1947. The gem was subsequently cut to yield a 23.68-ct internally flawless round brilliant, now known as the Williamson Pink (Balfour, 1987).

In January 1992, the Tanzanian Ministry of Water, Energy, and Minerals signed a diamond-prospecting agreement with De Beers Centenary AG's subsidiary Willcroft Co. and Tanex, a locally incorporated subsidiary of Willcroft "Tanzania signs major diamond deal," 1992). Using modern geophysical methods like remote sensing, they are scanning an area over 23,000 $\mathrm{km}^{2}$ in northern Tanzania, south of Lake Victoria and west of Mwadui. The newly developed method of nickel thermometry, which measures the nickel content of the garnet and chromite indicator minerals found in heavy mineral concentrates from kimberlites, provides a relatively inexpensive and fast test to distinguish between barren and potentially diamondiferous kimberlites (Griffin et al., 1991). Given the number of diamondiferous deposits already known, Tanzania holds the promise for other economically significant diamond mines.

\section{CORUNDUM}

Ruby. Background. Rubies and pink sapphires are found in the northern, northeastern, and central eastern areas of Tanzania: Longido, Umba River Valley, and Morogoro (figure 8), respectively (again, see figure 2). Ruby was first discovered in the early 1900s near Longido Mountain, close to the border with Kenya. Following World War I, the German officer credited with making the original discovery founded the Tanganyika Corundum Corp. and began mining at the locality now known as the Longido (also the Mdarara) mine. Longido was operated sporadically until 1971, when it was taken over by the Tanzanian government and subsequently closed. Reopened in 1988, it is now operated by the Longido Gemstone Mining Company-a joint venture between Tofco, a Swiss company, and Tanzania Gemstone Industries. The mine shaft is $3 \mathrm{~m}$ in diameter and $100 \mathrm{~m}$ deep. Explosives and pneumatic drills are used to penetrate the host rock, which is then brought to the surface using rail wagons (C. Garcea, pers. comm., 1992).

Figure 7. Tanzania is known for its production of pink diamonds as well as near-colorless and green stones. This 2.90-ct diamond is known as the De Young Pink. Courtesy of the Smithsonian Institution, Washington, DC; photo@ Tino Hammid.

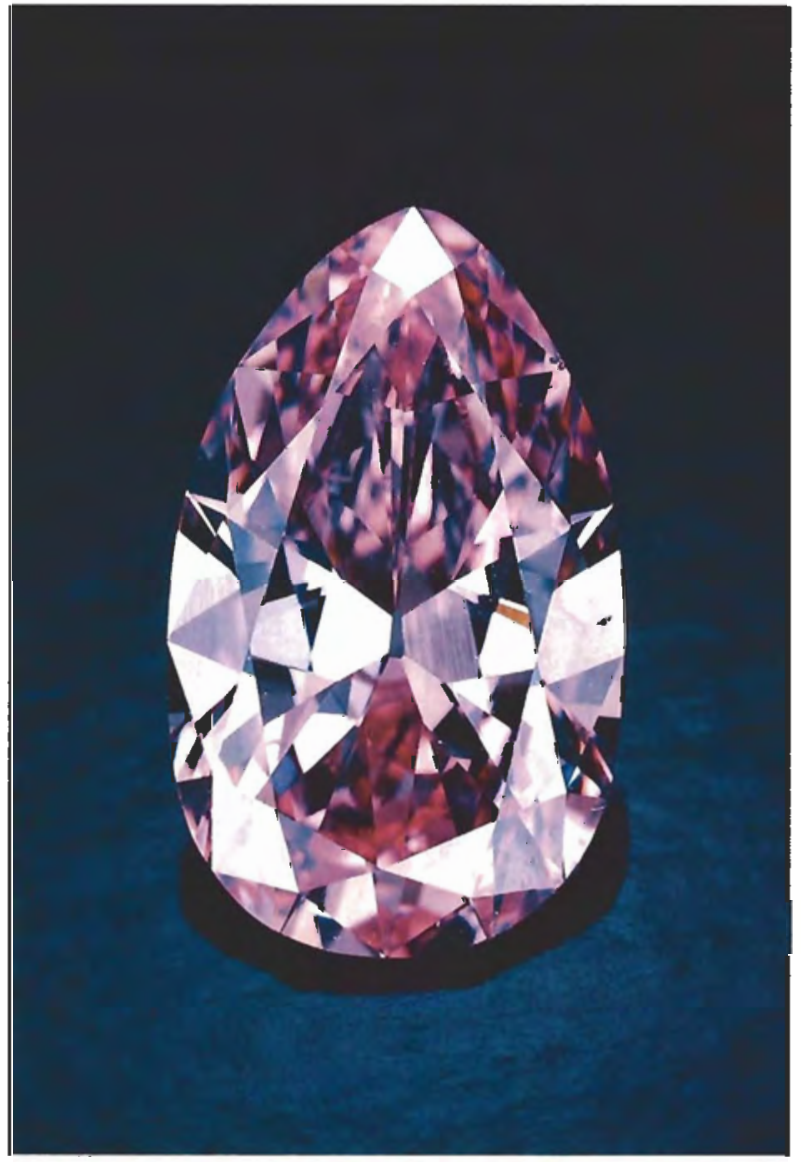




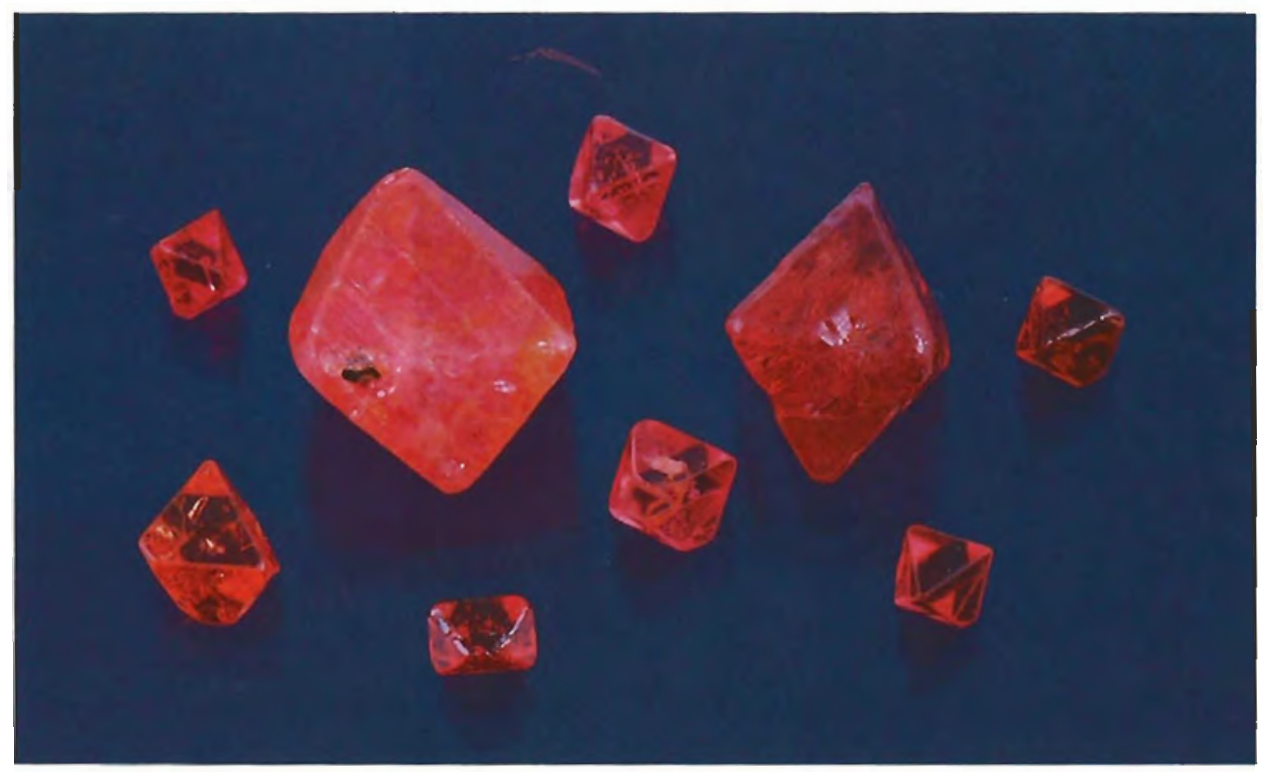

Figure 9. Rubies (here, the two large crystals) have been found mixed with spinels in parcels from the Morogoro area. These pseudo-octahedral ruby crystals are ringed by seven smaller spinel octahedrons, all from Morogoro. Photo by Shane McClure.

$\mathrm{km}$ southeast of Arusha. In the past, ruby rough mined in the area around Landanai and Lossogonoi produced facet-grade stones in the one-carat range (N. Barot, pers. comm., 1992), but this deposit is no longer active.

One of the first geologists to report on the gem corundums of the Umba Valley, Solesbury (1967), maintained that both rubies and sapphires found in this area originally formed in pegmatites cutting a serpentinite / the first of the four types of primary ruby deposits listed above). The serpentinite (actually a "pipe"; C. Bridges, pers. comm., 1992/ occupies the core of a fold in the Usagaran granulite rocks.

In the Morogoro area, rubies are found as alluvial deposits or as lenses in calc-silicate rocks within the marbles (the fourth type of primary ruby deposit mentioned) of the Usagaran granulite type rocks (Msolo, 1992).

Description of the Material. For the most part, the gemological properties of the various Tanzanian rubies are consistent with those of rubies from various other localities (Bank, 1970; Zwaan, 1974; Schmetzer, 1986). However, differences in chemistry, crystal morphology, and internal features have been reported, even for rubies that are believed to come from the same area (e.g., Morogoro; Hänni and Schmetzer, 1991).

Recent geochemical studies help explain the hues of rubies from the various Tanzanian deposits as compared to rubies from other localities. Although the chromium content of Morogoro and Umba rubies is relatively low in comparison to those from Myanmar (Burma), the amount of iron is similar to that in Burmese rubies and is considerably less than that identified in other Southeast Asian stones. Typical Morogoro-area rubies have the least iron, Longido has more, while Umba River specimens have the most (Hughes, 1990; Hänni and Schmetzer, 1991; Key and Ochieng, 1991b). Some of the Tanzanian rubies are heat treated in Thailand in an attempt to improve color and clarity. To date, such treatment has had mixed results (K. Schmetzer, pers. comm., 1992).

Figure 10. Spectactlar rubies, like this 1-gram crystal and 0.87-ct pear shape, are being produced at the increasingly important Marazi deposit in Morogoro. Stones courtesy of Dr. Horst Krupp and Pala International; photo (C) GIA and Tino Hammid.

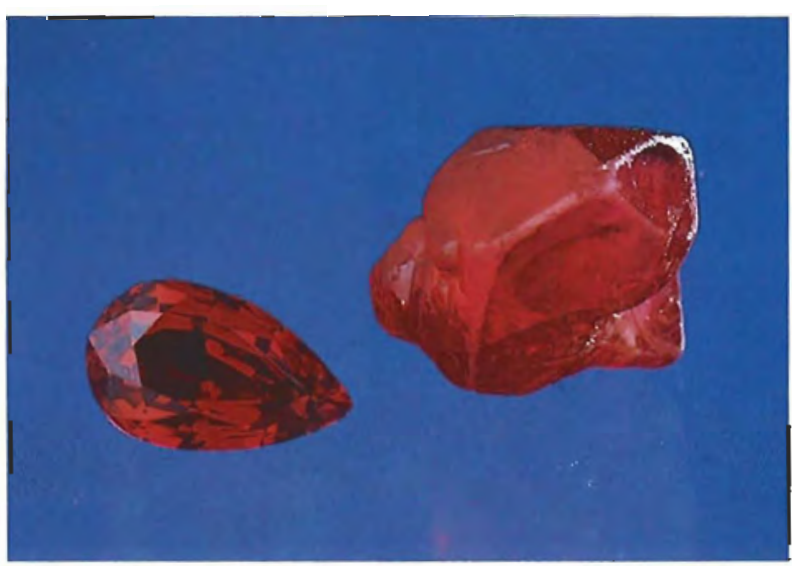




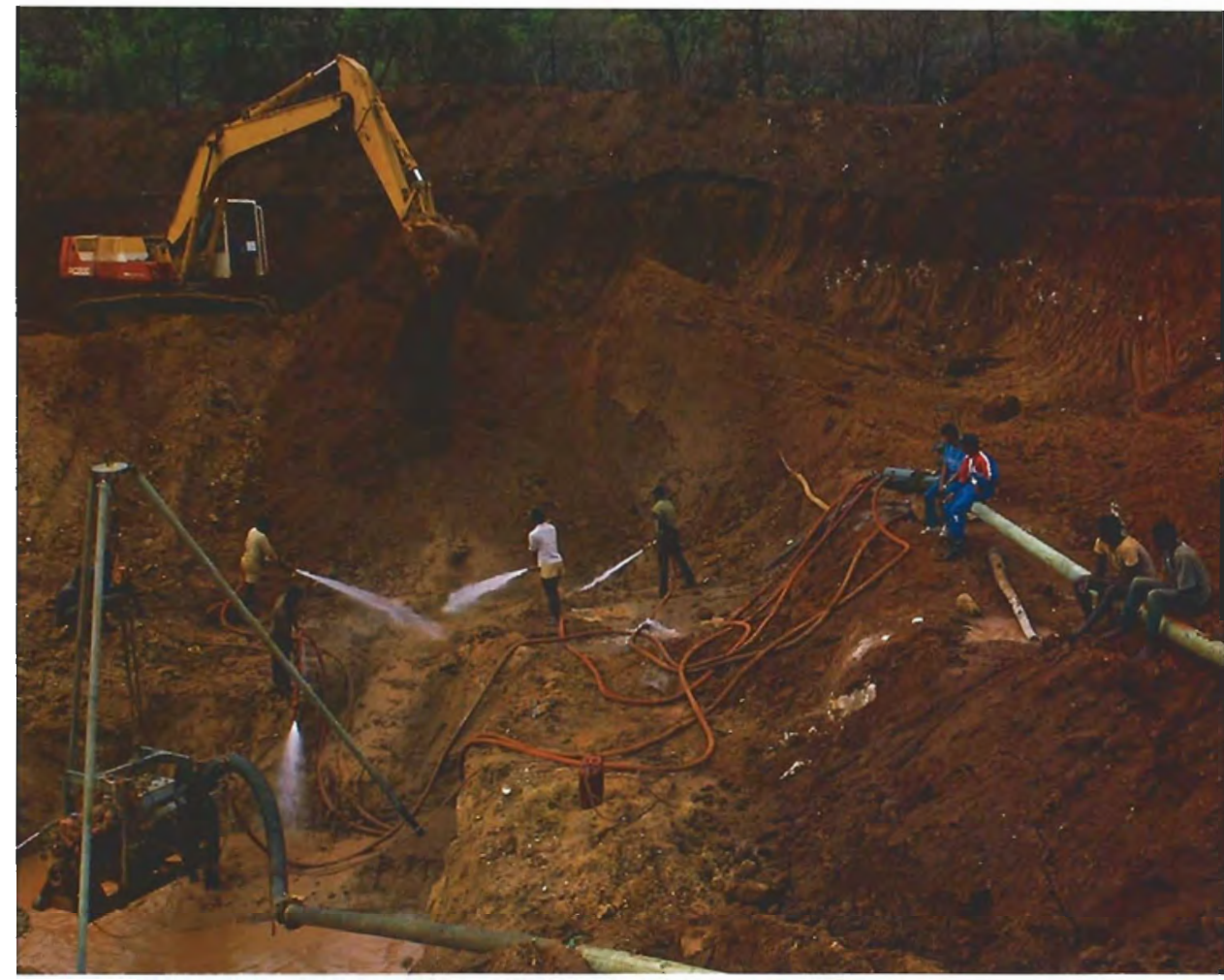

Figure 11. In the valley of the Umba River, mechanized mining is now used to recover conundum and associated gems from the rich gem gravels. Photo (C) Fred Ward.

Current Production and Future Potential, Mining at Longido produces, at best, about one ton of ruby per month; only about $1 \%$ of this is cabochon grade and an even smaller fraction is facetable, with the remainder suitable for carving. Faceted transparent stones seldom exceed one carat. Reserves at Longido appear to be sufficient to maintain production at this level for several years.

Figure 12. These are only a few of the many colors of sapphire mined from the Umba Valley. The average sapphire is approximately $3 \mathrm{ct}$. Courtesy of Gems of Africa, Los Angeles, CA; photo by Robert Weldon.

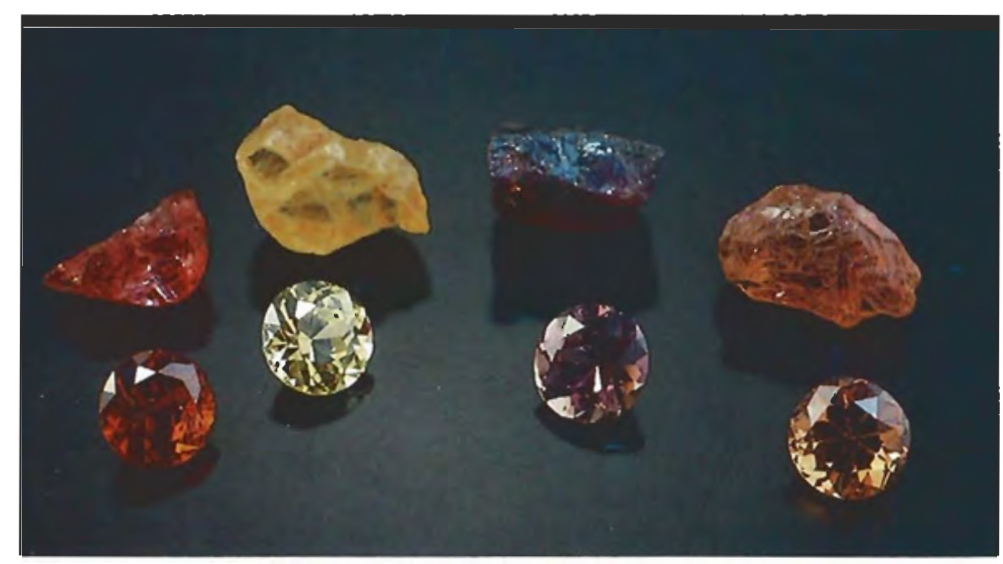

In the 1960s and 1970s, miners at Umba occasionally found pieces of rough that yielded cut rubies as large as 20 ct (R. Naftule, pers. comm., 1992). Although official reports indicate that there is now virtually no production from the Umba River region, mining of both primary deposits and alluvial gravels continues, and is now done with the help of bulldozers and backhoes (figure 11). This level of activity, and the extent of gem trading in nearby villages and towns, suggests that economic quantities of gemquality ruby and sapphire are being recovered, and such mining will undoubtedly continue in the future (Ward, 1991).

Currently, hundreds of miners are operating at the various localities in the Morogoro area (Msolo, 1992). Dr. N. Barot (pers. comm., 1992) estimates that the total production from these deposits is approximately $200 \mathrm{~kg}$ per month of gem ruby-mostly cabochon and carving grade.

Sapphire. Background. The Umba River Valley has yielded sapphires in virtually every color as well as change of color. To date, this is the only region that produces gem-quality sapphires, although there are reports of other sapphire occurrences in the vicinity and pink sapphires have been identified with rubies in the Morogoro area, as noted above. Sapphires were first discovered in the 1950s, in alluvial gravels of the Gerevi Hills north of the Umba River (Solesbury, 
Figure 13. The Umba Val-

ley is also noted for its production of color-change sapphires. This 8.74-ct sapphire is blue in day or fluorescent light and purple in incandescent light. Courtesy of S. L. Dillon; photo (c) Tino Hammid.
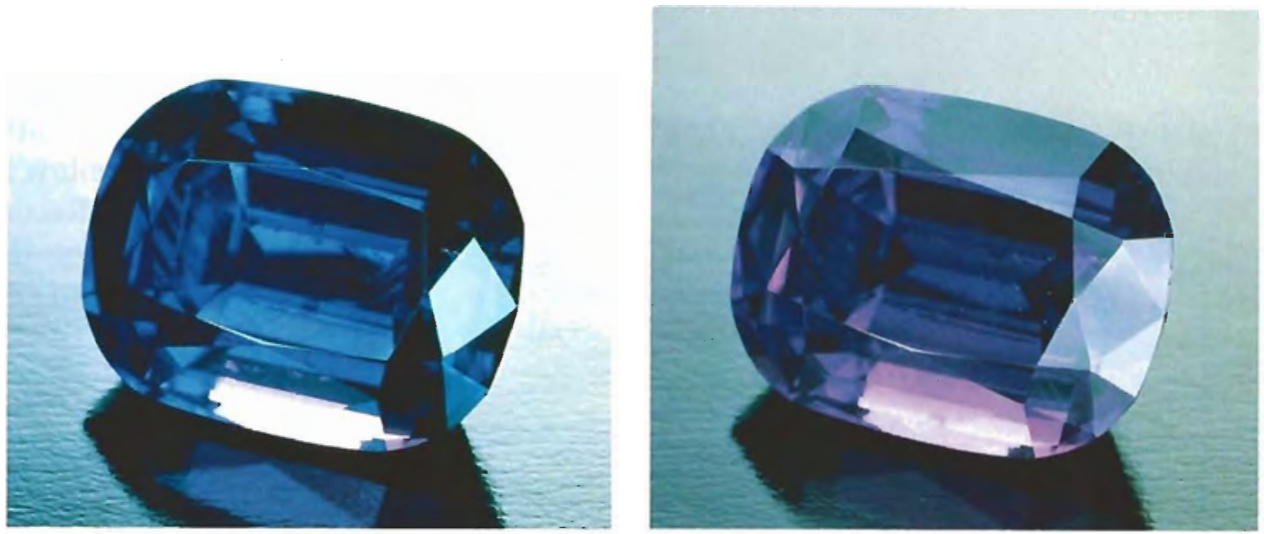

1967). As mentioned above, Umba Ventures was formed in 1961; they worked the nearby primary deposit as well as the alluvial deposits (Sarofim, 1970). As with the other gem deposits, mining was halted for much of the 1970s and early 1980s, but activity resumed in 1986.

Geology. At Umba, the sapphires-like the rubiesformed in association with pegmatite veins that cut a serpentinite body in the Umba River Valley metasediments (Solesbury, 1967). Today, the miners are working secondary deposits almost exclusively. The main mine now extends to $100 \mathrm{~m}$ below the surface, with tunnels radiating from the primary shaft on the gem-bearing levels (N. Barot, pers. comm., 1992; again, see figure 9).

Description of the Material. For the most part, the gemological properties reported for Tanzanian sapphires overlap those of sapphires from other localities (Webster, 1961b; Bank, 1970; Zwaan, 1974; Schmetzer, 1986). They are most notable for their great range of colors: colorless, violet, purple, blue, green, orange, yellow, yellow-orange, red-orange, pink, parti-colored, and change of color (figure 12). The parti-colored sapphire crystals tend to be pale in the center and have a deeper hue around the edges (Pough, 1971; Bridges, 1982). Many of the Umba sapphires exhibit change of color such as greenish to grayish blue in dayor fluorescent light and deep purple to purplish red in incandescent light (figure 13). This unique range of colors is caused by variations in the proportions of the chromophores chromium, iron, manganese, nickel, titanium, and vanadium (Zwaan, 1974; Schmetzer, 1978).

Alluvial sapphire rough is usually found as rounded pebbles that produce stones of one carat or less. However, faceted stones as large as $40 \mathrm{ct}$ and cabo- chons up to $90 \mathrm{ct} \mathrm{have} \mathrm{been} \mathrm{cut} \mathrm{from} \mathrm{pieces} \mathrm{of} \mathrm{rough}$ weighing hundreds of grams (R. Naftule, pers. comm., 1992).

Some members of the trade label Umba's orange sapphire "African padparadscha" (figure 14), although the trade name padparadscha is usually restricted to the delicate pinkish orange Sri Lankan sapphire. In the past, orange sapphires did not meet the generally accepted criteria for "padparadscha" (Crowningshield, 1983; Henn and Bank, 1992). However, East African sapphires with the more classic hues of padparadscha were seen at both the 1991 and 1992 Tucson shows.

Some of the pale sapphires are being heat treated in Thailand. Although all of the stones will be affected, the resulting color is often not commercially desirable (K. Schmetzer, pers. comm., 1992). The GIA Research Department heat treated three orange-pink sapphires from the Umba River region in a strongly reducing atmosphere, at $1700^{\circ} \mathrm{C}$, for $18-21$ hours.

Figure 14. The orange sapphires from Umba are distinctive for their saturation. Here, the orange rough is $3.80 \mathrm{ct}$ and the cut stone is $1.04 \mathrm{ct}$. Courtesy of Don Clary; photo by Robert Weldon.

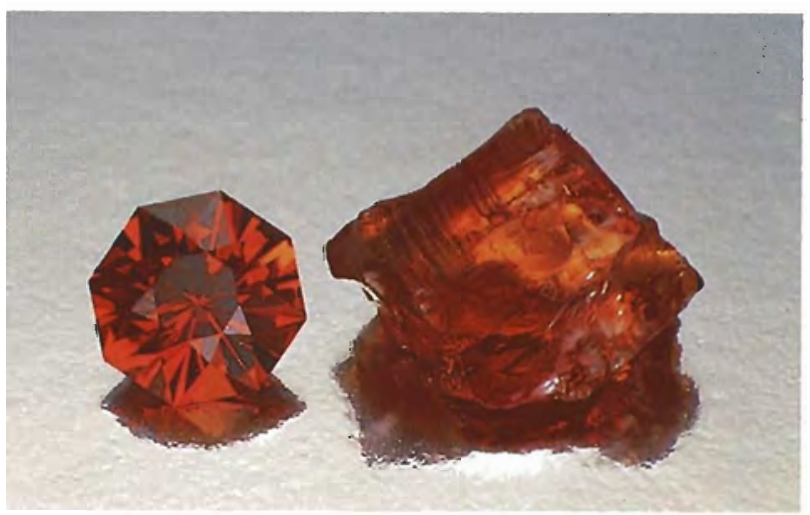




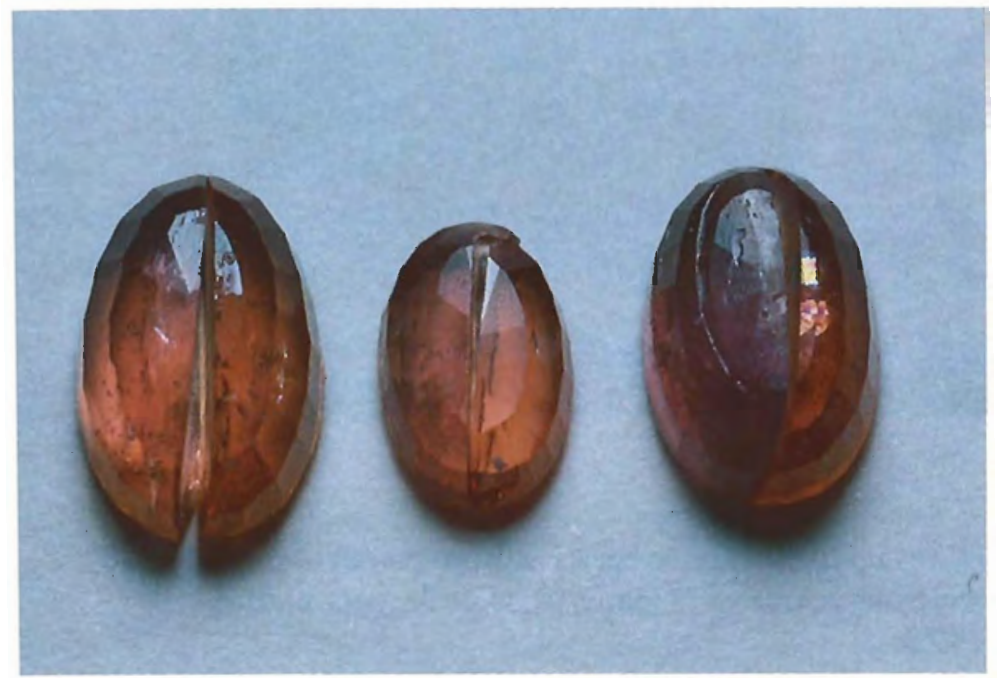

Figure 15. The Umba Valley sapphires reportedly do not respond to heat treatment as well as sapphires from some other localities. These three sapphires from the Umba Valley were cut and the left half of each heat treated to provide some idea of the extent of the change produced. Stones and experiment courtesy of the GIA Research Department; photo (C) GIA and Tino Hammid.
These stones showed little change of hue (figure 15), but the fading of yellow and production of violet color was interesting. Recently, it has also been reported that some of the material is being "quench crackled" and dyed to simulate ruby (Schmetzer and Hänni, 1992).

Current Production and Future Potential. As with rubies from this area, officially there is no current production of sapphires in the Umba River valley. Again, however, the extent of mining activity and local gem trading indicates that the area is still producing facet-grade sapphires in all colors (Ward, 1991). R. Naftule reports that a single pocket found at Umba in 1990 contained $10 \mathrm{~kg}$ of rough red-orange to orange sapphire that yielded stones as large as a carat (pers. comm., 1992).

\section{ZOISITE (TANZANITE)}

Background. Zoisite belongs to the epidote group of minerals. Its most famous gem variety is purplish blue tanzanite (again, see figure 1). However, Tanzania also produces the opaque green variety anyolite

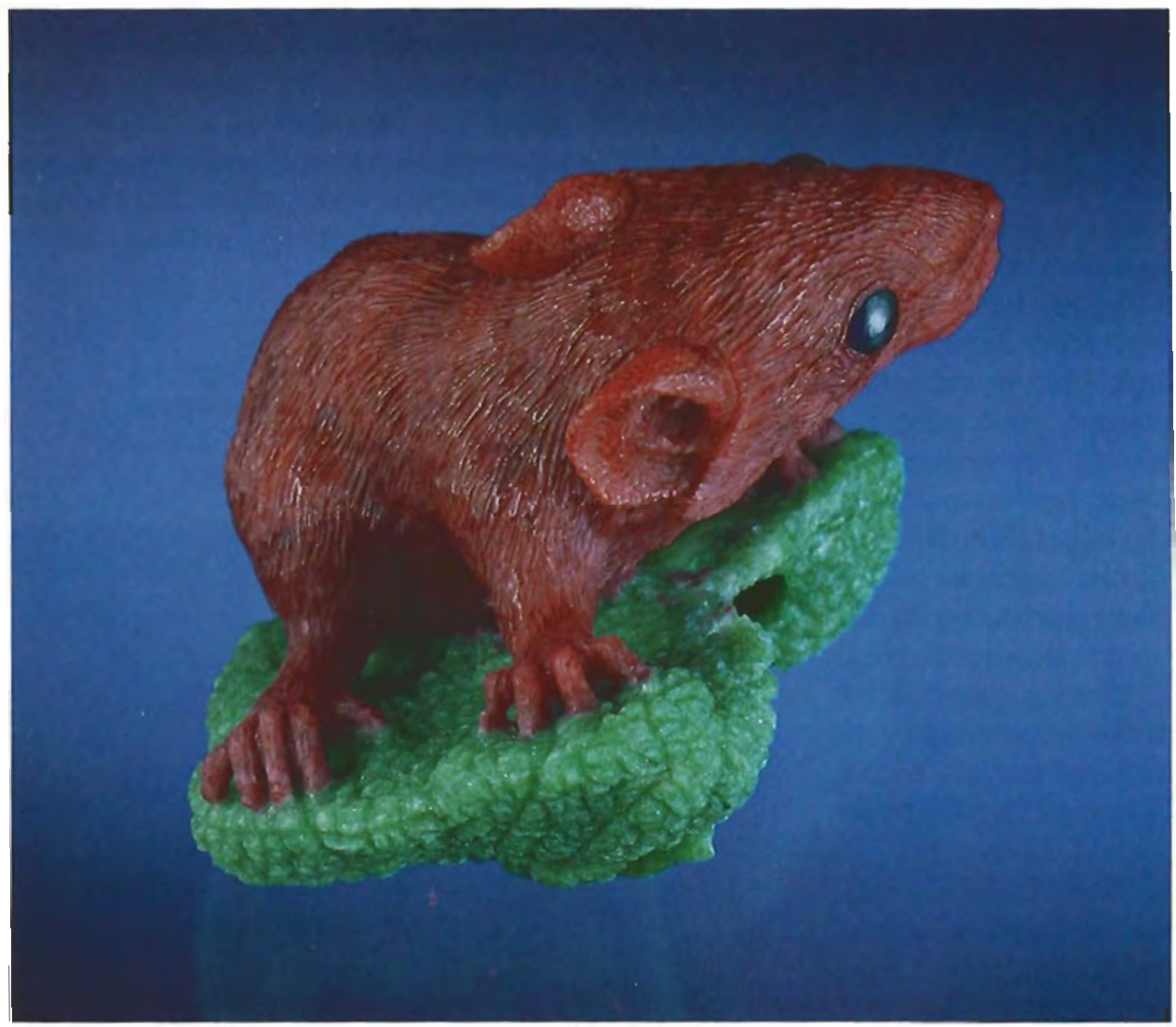

Figure 16. The earliest variety of zoisite seen in the gem industry was the opaque green material that commonly occurs with ruby. It is a superb carving material, as illustrated by this ruby field mouse sitting on a green zoisite leaf. The carving-actually made from a single piece of ruby in zoisite-measures $45.13 \mathrm{~mm}$ high by $62.64 \mathrm{~mm}$ wide by 55.72 $\mathrm{mm}$ deep. Carving by Gerd Dreher, courtesy of Silverhorn, Santa Barbara, $C A$; photo (C) GIA and Tino Hammid. 
Figure 17. Most of the opaque green zoisite is mined at Longido. Here a

miner works a pillar of green zoisite underground at Longido. Photo courtesy of Carlos Garcea.

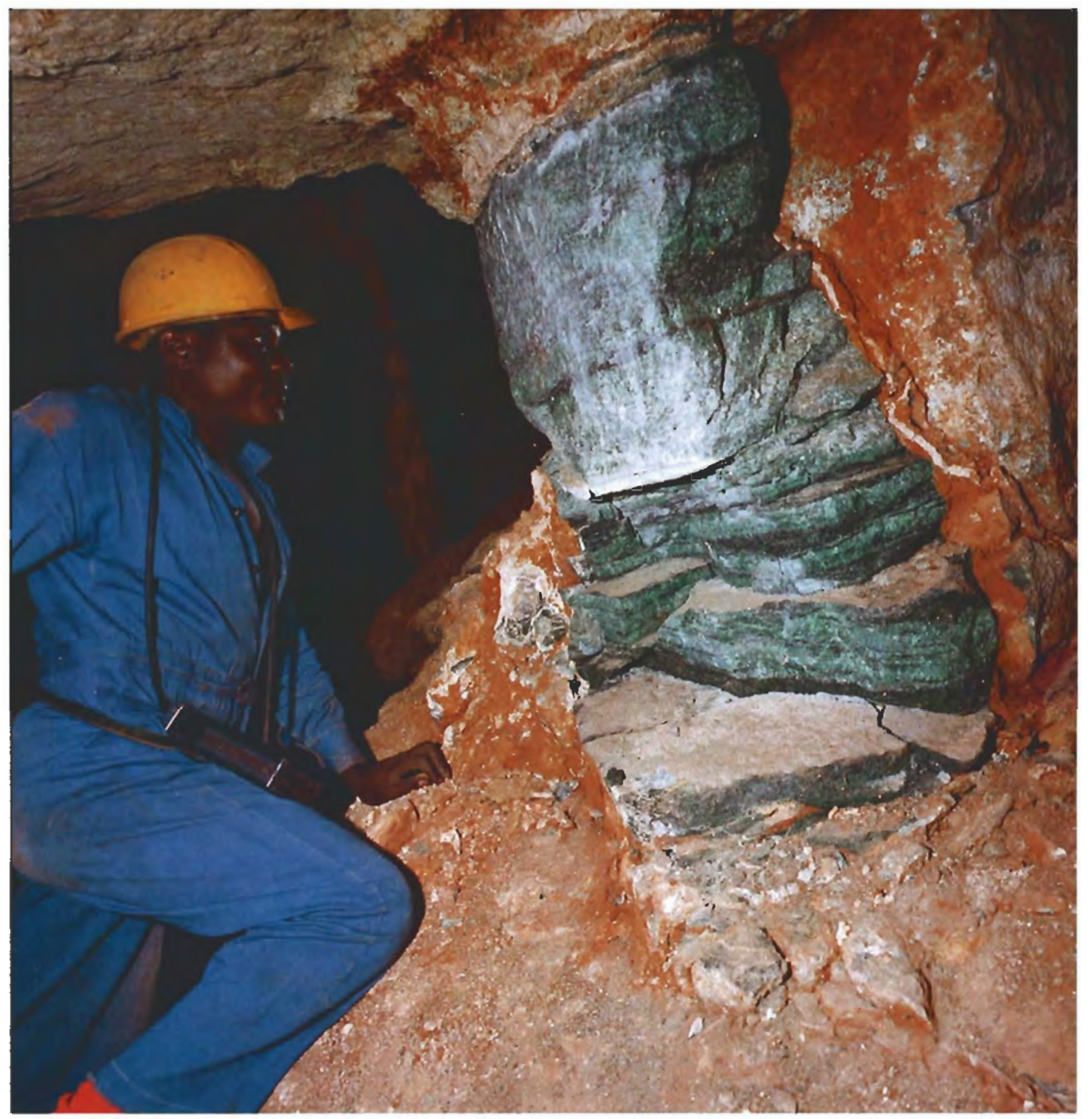

(Gübelin, 1969), as well as limited quantities of transparent zoisite in a number of hues (including green, yellow, pink, and violet; Barot and Bochm, 1992).

Before the discovery of tanzanite, the most notable zoisite in Tanzania was anyolite, which occurs with ruby. This unique combination makes a dramatic carving material (figure 16). It is mined underground at Longido (figure 17).

The gem community's appreciation of this species changed dramatically when transparent blue zoisite was discovered in the 1960s. It was first identified in 1962 by George Kruchiuk, who had received several samples that were purported to be blue sapphire; Manuel D'Souza is credited with discovering the location of the deposits while prospecting for ruby in the Merelani Hills (again, see figure 2) in the Lelatema district (Bank, 1968; Hurlbut, 1969; Webster, 1983). Tanzanite was first marketed in the United States in 1968 by Tiffany \& Co. ("Tiffany discloses ...," 1968), which named the gem in honor of its country of origin.

Private prospectors and local miners worked the
Merelani Hills deposits until nationalization was started in 1971. The supply of tanzanite was sporadic until 1988, when the government temporarily opened the area and 20,000 miners descended on it. Working day and night, they dug hundreds of pits and recovered many thousands of carats of tanzanite. In late 1990, however, the government sought to establish greater control over the number of miners and the flood of tanzanite into the world market. Ultimately, the Tanzanian army was deployed to remove the miners and patrol the locality (Federman, 1991).

The government has since divided the tanzanite area into four sections, or blocks, and awarded mining contracts for each block to a different joint venture (see A. Suleman's report in Koivula and Kammerling, 1991c). Today, all are being mined and are beginning to be mechanized. The government also marked out several small blocks southwest and northeast of blocks $A$ and D, respectively, and has already invited offers from Tanzanian firms and individuals. 


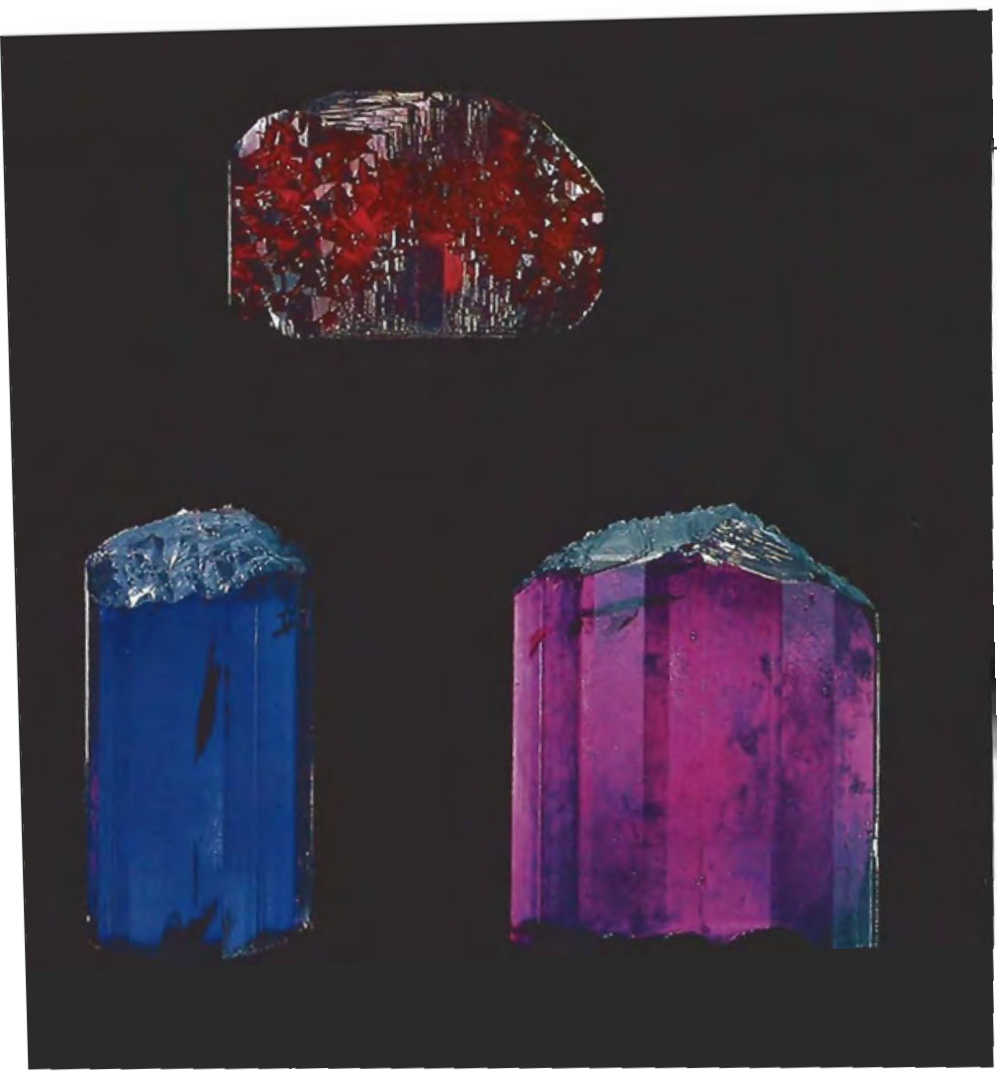

Figure 18. Tanzanite is known for its distinct pleochroism, but this is one of the most spectacular examples ever recorded. Shown here are the colors seen along the three axes of this superb crystal, called the "Sleeping Beauty of Tanzania," which weighs 176 grams and measures $55 \mathrm{~mm}$ high $\times 43 \mathrm{~mm}$ wide $\times 28 \mathrm{~mm}$ thick. Note especially the deep red seen down the c-axis, which is usually brown. Courtesy of the John Barlow Collection; photo (C) Harold \& Erica Van Pelt.

Geology. Tanzanite is found in both primary and secondary deposits. Malisa (1987) describes the primary tanzanite deposits as occupying the crest of the large Lelatema fold, which is composed of metamorphic rocks (e.g., dolomite marbles, graphitic gneisses, and schists) and is separated from the surrounding plateau by large faults. Hydrothermal solutions injected into local faults and fissures reacted with the bedrock to begin the tanzanite mineralization. The gneisses at Merelani were folded during the many stages of movement that followed. As a result, tanzanite-sometimes associated with green grossular garnet-is most commonly found in cavities in the metamorphic rocks or at the contact with quartz veins in the hinges of folds that can be tens of meters wide.

Description of the Material. One of the most notable features of tanzanite is its strong pleochroism, which is usually grayish blue, purple, and brown, green, or yellow. Red replaces brown in some crystals (figure 18; see also A. Bassett, as reported in Koivula and Kammerling, 1991bl. Most of the gem-quality tanzanite recovered appears brown face-up when cut. The color in approximately $95 \%$ of the purplish blue tanzanites on the market today has been produced by heating the crystals to approximately $600^{\circ}-650^{\circ} \mathrm{C}$, which results in a change in the valence state of the vanadium $\left(\mathrm{V}^{3+}\right.$ to $\mathrm{V}^{4+}$; Anderson, 1968; R. Naftule, pers. comm., 1992) and converts the brown (or yellow or green) pleochroic color to blue. The extensive mining in recent years has produced unusually large quantities of tanzanite as well as extremely large crystals, some well over 100 grams.

Small quantities of transparent zoisite crystals are also found in other colors: greenish blue, green, yellow, and pink, as well as violet to reddish purple, colorless, change of color, and bicolored (Barot and Boehm, 1992; R. Kane and R. Naftule, pers. comm., 1992; figure 19|. The most significant recent development has been the commercial production of transparent green zoisite (Barot and Boehm, 1992). Found at Block B, gem-quality pieces as large as 19 grams have been recovered from this primary deposit. The color ranges from a dark petroleum-like green to yellowish ("olive") to bluish green to green to a greenish blue. The "purity" of the green depends on the amount of chromium relative to vanadium present in the stone: "Pure" green stones show more chromium than vanadium; yellowish or bluish green stones show a higher vanadium content (Schmetzer and Bank, 1979; Barot and Boehm, 1992).

Current Production and Future Potential. Although there are more fine, large tanzanites on the market today than ever before, we do not know if the level of production achieved before the block system was established will be maintained. Even so, it appears that there is still a large stockpile of tanzanite among the independent miners: Many used the money they originally received for their tanzanite to purchase more tanzanite. "While termites will eat paper money, they are no threat to the gems, " which can be safely stored for future sales (H. Krupp, pers. comm., 1992).

\section{GARNET}

A number of unusual garnets have been found in Tanzania: pyrope-spessartine (malaya), pyrope-almandine (rhodolite), green grossular (tsavorite), pyrope, and change of color. In fact, changes recommended in the gemological classification of species of the garnet group are largely the result of the availability of these 
Figure 19. Transparent zoisite actually occurs in a wide range of colors. These zoisites are all from the Merelani area; the yel-

low gen weighs $9.36 \mathrm{ct}$, the blue tanzanite at the upper right weighs $7.14 \mathrm{ct}$, and the green zoisite at the lower left weighs 2.54 ct. Courtesy of Pala International, Fallbrook, $C A$; photo (C) Harold es Erica Van Pelt.

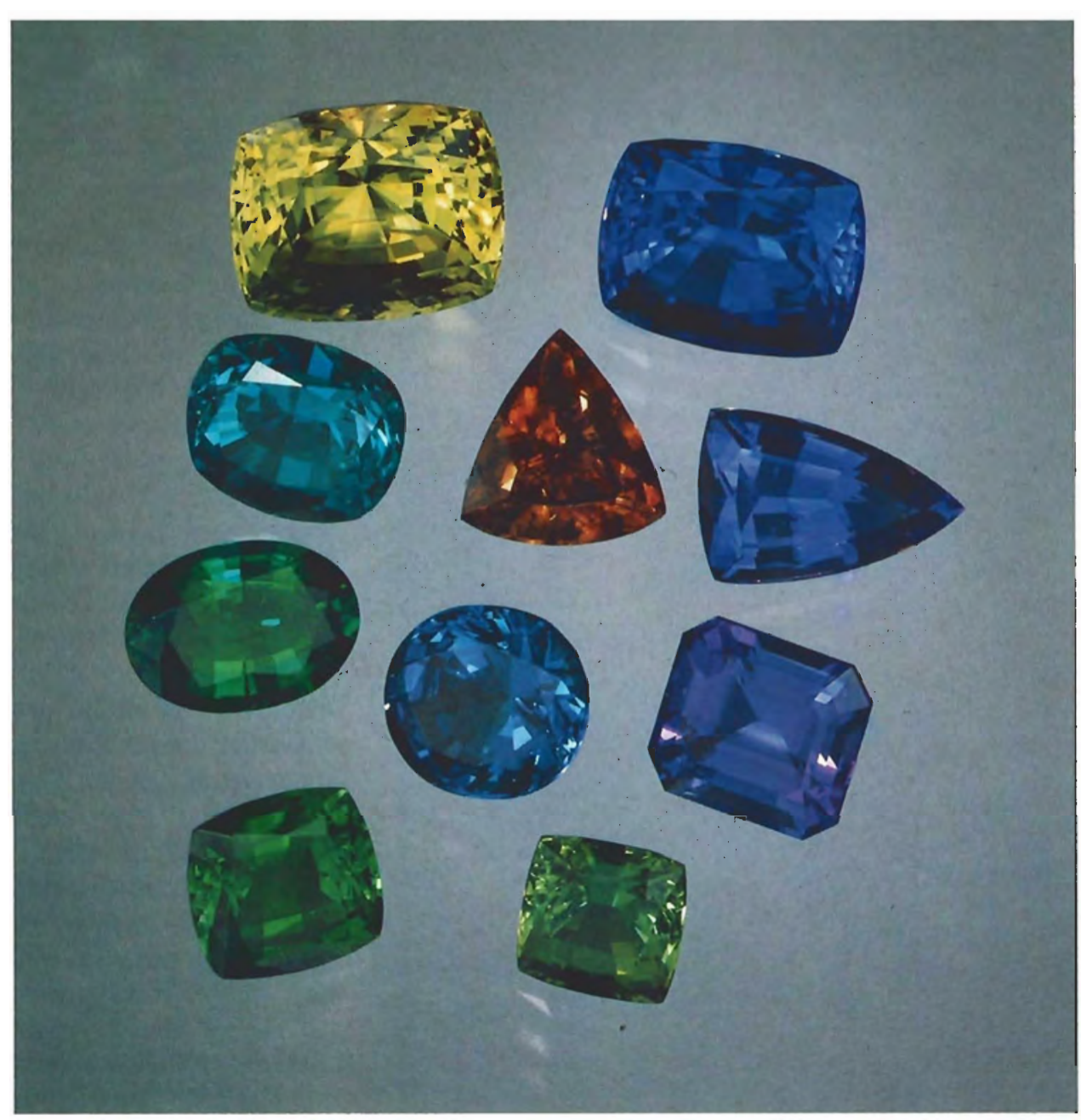

new garnets (see Stockton and Manson, 1985, for an in-depth discussion of this new classification). The hues represented by Tanzanian garnets include green, purplish red, orange, and various pastel shades (figure 20) - the result of variations in iron, manganese, chromium, and vanadium content. The most economically important garnets from Tanzania-malaya, tsavorite, rhodolite, and change of color-are discussed individually below.

Malaya (Malaia). This red-orange to yellow-orange garmet (figure 21) is found in alluvial deposits along the Umba River and in several plains that stretch from the Tanzanian border with Kenya north to the Mgama Ridge in the Taita Hills (Curtis, 1980). Malaya garnet was discovered in the mid-1960s by miners extracting rhodolite for George Papas in the Umba River Valley (R. Naftule, pers. comm., 1992). First thought to be spessartines, in the early 1980s they became known by the Swahili name malaya (which translates as "out of the family," or "outcast"), because their properties did not place them into traditional garnet categories.
Not only has malaya (malaia) garnet been known by two different spellings, but it is also known as pyralspite (Winchell, 1937) after its mixture of pyrope, almandine, and spessartine (although its almandine content is generally low) and as "umbalite" because of its discovery in the Umba Valley (Jobbins et al., 1978; Schmetzer and Bank, 1981; Stockton and Manson, 1985).

Malaya garnet is a member of the garnet solidsolution series pyrope-spessartine, with significant amounts of almandine and grossular; the Umba Valley malaya garnets show a broad variation in chemistry (Schmetzer and Bank, 1981; Stockton and Manson, 1982). After cutting, malaya garnets often exhibit red scintillation flashes, possibly the result of traces of vanadium and/or chromium, that enliven their appearance.

Tsavorite. This transparent green grossular garnet has been found in the hills southeast of the village of Komolo (figure 22), in the Lelatema Mountains (Bank et al., 1970), and in the Merelani Hills (Kane et al., 1990) of Tanzania, as well as in Kenya. Tsavorite 
Figure 21. Among the most unusual garnets found in Tanzania are these

malaya garnets, which were first recovered from alluvial deposits along the Umba River. The rough piece in the upper center is typical of the material found in Tanzania. The round mixed cut stone on the left weighs $22.99 \mathrm{ct}$. Courtesy of Pala International, Fallbrook, CA; photo (C) Harold en Erica Van Pelt.

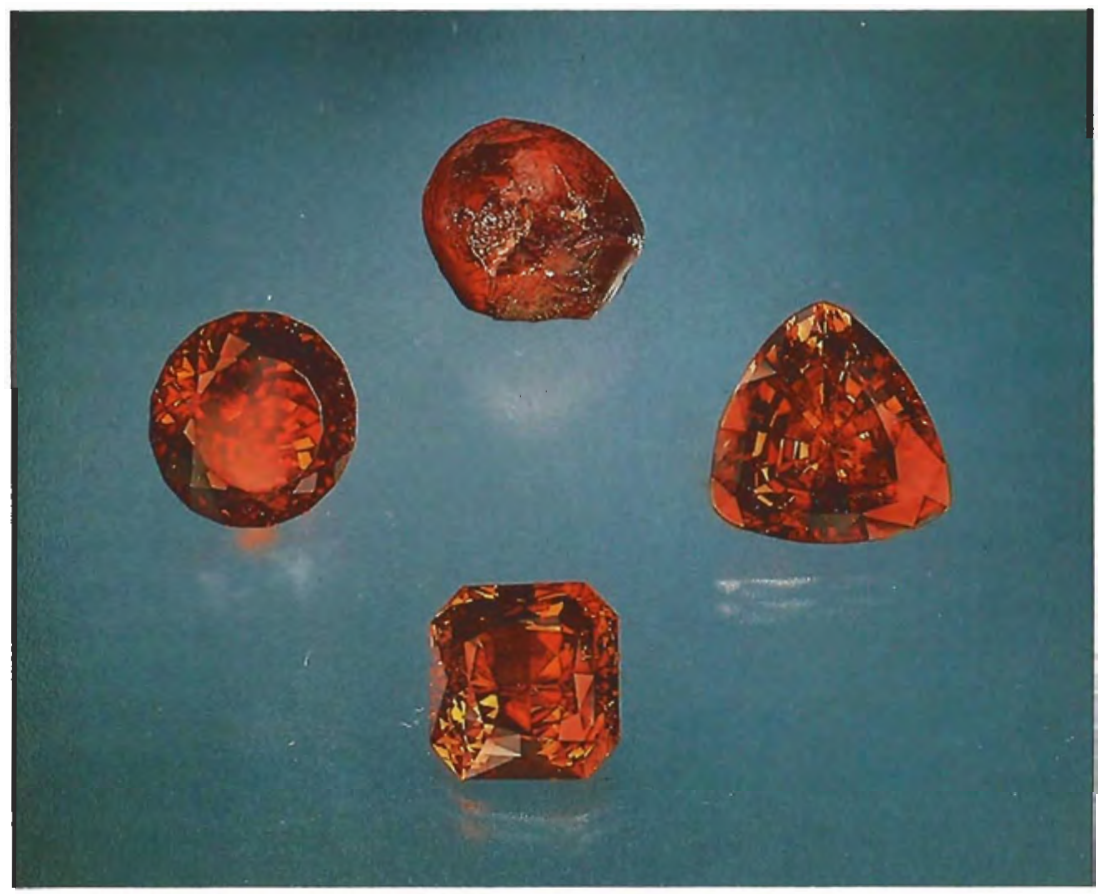

The only confirmed locality for change-of-color garnets in Tanzania is in the alluvial deposits at Umba, where they are usually found during the sorting process that follows recovery of other gem materials from this area. Color changes from red to orange, orange to pink, pink to purple, and orange to yellow have also been seen (see, e.g., figure 3).

Figure 22. Although commonly associated with Kenya, the green grossular gamet now known as tsavorite gamet was actually discovered in Tanzania. This 11.35-ct tsavorite garnet is from the Komolo deposits. Courtesy of Pala International; photo $($ Harold $\Theta$ Erica Van Pelt.

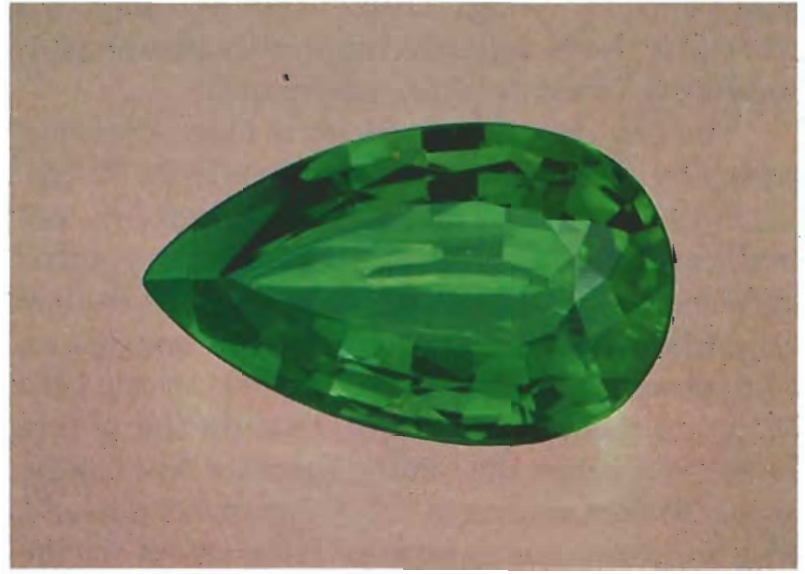

Current Production and Future Potential. At present, there is a continuous and significant production of garnets from most of the numerous localities in Tanzania. However, at a recent, much-publicized gem auction in Arusha, only 31 grams of tsavorite were offered for sale. Currently, garnets are found in the fol-

Figure 23. Spectacular rhodolites, like this 14.25-ct stone, have been found at a number of deposits in Tanzania. Courtesy of Mayer $e_{1}$ Watt, Beverly Hills, CA; photo $\odot$ GIA and Tino Hammid.

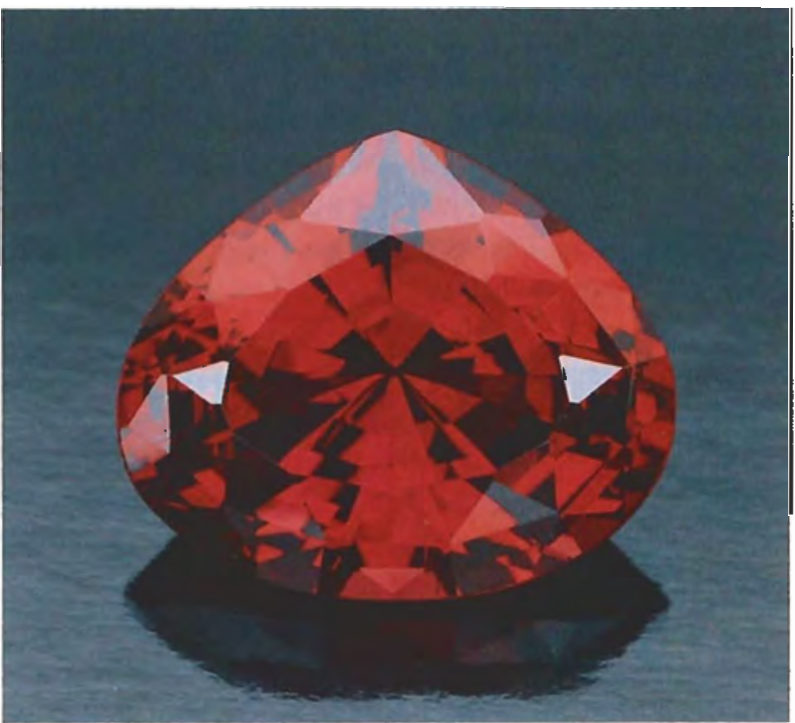




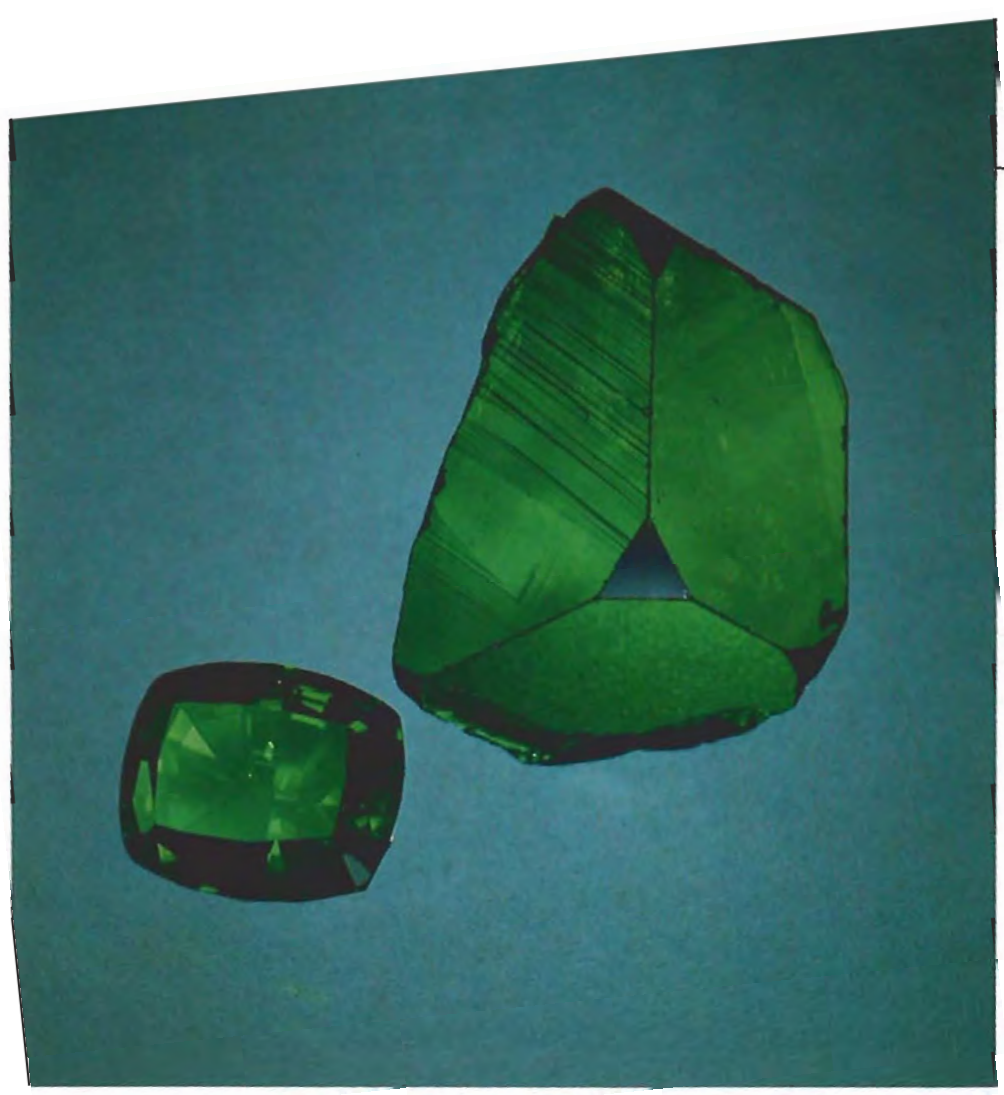

called "chrome" tourmaline in the trade (Schmetzer and Bank, 1979; figure 24). Other colors and phenomenal varieties include yellow, ranging from "golden" to orange; change of color (dark green in day or fluorescent light, and red in incandescent light); cat'seye; and, on rare occasions, bicolored-green and yellow-stones (figure 25).

The term "chrome" tourmaline has been used in the trade because chromium was originally thought to be the cause of color, as well as to distinguish these stones from the less "pure" green tourmalines typical of Brazil and other localities. H. Bassett reported this occurrence in the geologic literature in 1956, and subsequently identified vanadium as the cause of color. Bank (1982) found very little chromium present in the stones he examined at that time, although some green tourmalines from Tanzania tested since then have had higher contents of chromium than vanadium (Bank and Henn, 1988).

Figure 24. Tanzania is noted for the superb "chrome" tourmalines found there. This approximately $2.5 \times 4 \mathrm{cnz}$ rough crystal and the accompanying 5.10-ct faceted "chrome" toumaline are from Landanai. Courtesy of Pala International, Fallbrook, CA; photo (c) Harold (4) Erica Van Pelt.

lowing relative abundances (from most to least): rhodolite, malaya, tsavorite, change of color.

\section{TOURMALINE}

Background. A number of species of the tourmaline group-elbaite, uvite, and dravite-are found scattered throughout northem and eastem Tanzania (Webster, 1961a; Zwaan, 1974; Herschede, 1986; Dietrich, 1985). However, there is little organized mining of tourmaline in Tanzania. Most of the material produced to date is the result of two small operations in Landanai, as well as those tourmalines found as byproducts of alluvial mining for ruby, sapphire, and garnet at Umba. Tourmaline of a magnificent bluish green color occurs near Daluni.

Geology. In Tanzania, tourmaline is typically found in either crystalline limestone or in pegmatites associated with limestone and/or ultramafics (Bridges, 1982). Elbaite is found primarily in pegmatites, whereas dravite and uvite occur in various types of metamorphic rocks.

Description of the Material. The most notable Tanzanian toumaline is the bright green variety of dravite

Current Production and Future Potential. Production of tourmaline reached a peak in the 1960s, when several hundred kilograms were recovered. Although most of the stones were under one carat, approximately $20 \%$ of the rough yielded 1 - to 10-ct stones $(R$. Naftule, pers. comm., 1992). By the early 1980s, only 2,400 grams of rough were recovered annually, which yielded about 2,400 ct of faceted stones /Herschede, 1986). Since then, production has been sporadic. Today, although thousands of carats of low-grade tourmaline are recovered in Tanzania, only a small quantity of new facet-grade material enters the market each year.

\section{EMERALD}

Background. The primary emerald deposit in Tanzania is about $3 \mathrm{~km}$ west of Lake Manyara and south of Maij Moto Hot Springs. Themelis (1989) reports that emerald is also being recovered near Sumbawanga, in southwest Tanzania (again, see figure 2).

The first emerald crystals were found in eluvial gravels by a local farmer and identified by H. P. Kristen in 1969. Kristen, a prospector, discovered the primary deposit at Lake Manyara the following year and immediately started mining the area. He worked for Galai Mining Company, owned then by George Papas, who subsequently established 25 claims around Lake Manyara (Rwezaura, 1990). During the period 1970-1973, before the mining operation was nationalized, Kristen recovered 231,877 grams of emerald, with some crystals as large as 150 grams /Gübelin, 


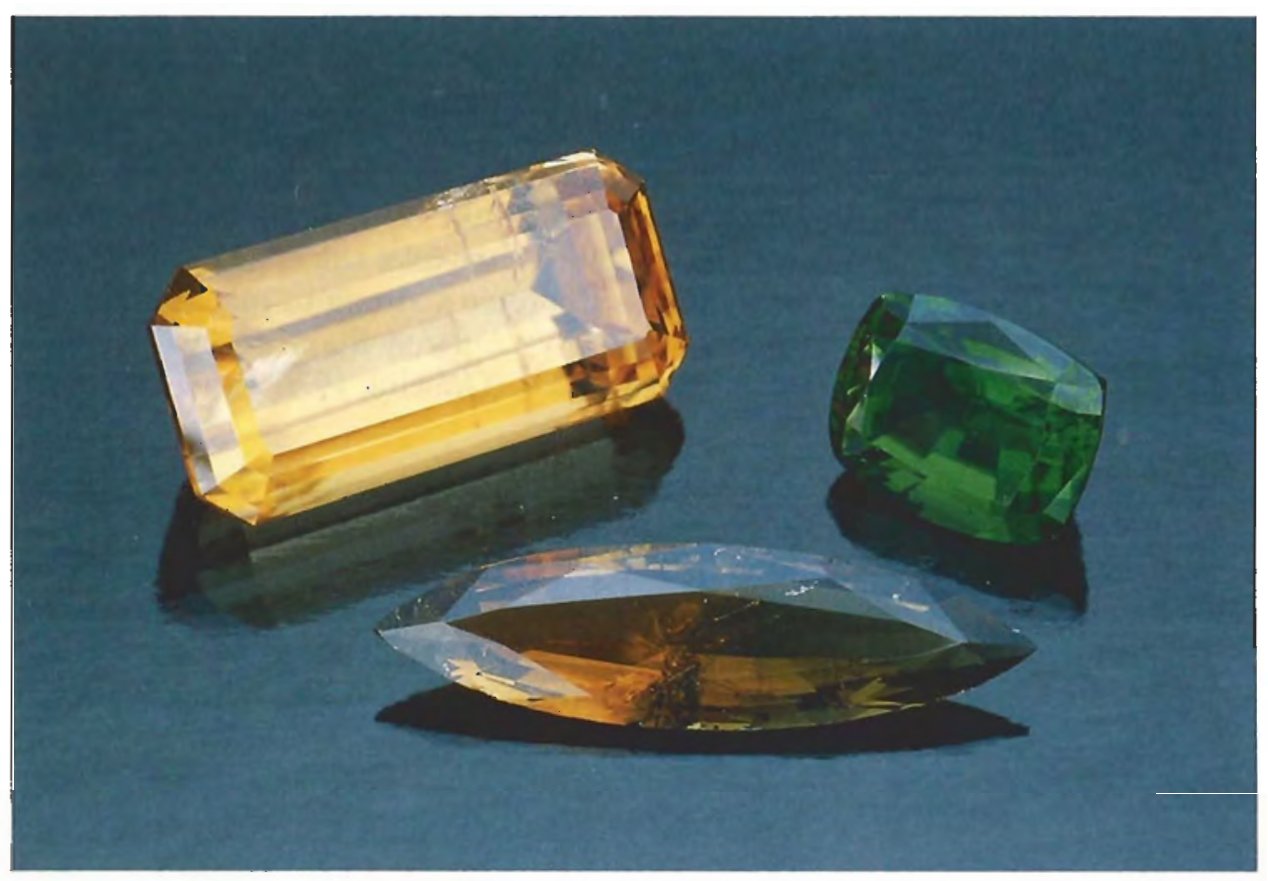

Figure 25. Toumalines have also been found to occur in various deposits in Tanzania, and in some aturactive and even unusual colors like those illustrated here. The orange tourmaline weighs $9.49 \mathrm{ct}$; the "chrome" tourmaline is $2.39 \mathrm{ct}$, and the rare bicolor weighs $1.82 \mathrm{ct}$. Courtesy of Overland Gems, Los Angeles, CA; photo $\mathbb{C}$ GIA and Tino Hammid.

1974). Today, small-scale mining continues and, at present, the mine is leased by Tofco.

Mining at Sumbawanga has progressed rapidly since the; discovery of emeralds there in early 1988; the main shaft is more than $13 \mathrm{~m}$ deep, with at least 18 tunnels radiating from it. Although the heavily included crystals average $20-30 \mathrm{ct}$, specimens up to $100 \mathrm{ct}$ have been recovered (Themelis, 1989).

Geology. The Lake Manyara emeralds are found in biotite schists interspersed with pegmatite and quartz segregations (Bridges, 1982). Several gems in addition to emerald are known to occur in the Lake Manyara vicinity. These include: apatite, garnet, spinel, ruby, sapphire, yellow chrysoberyl, and alexandrite /Gübelin, 1974). Eight areas have been identified on the Ufipa plateau as having potential for green beryl (Rwezaura, 1990). The Sumbawanga emerald deposit also occurs in a biotite schist. In both mining areas, blasting and backhoes are required to break up the host rock and remove it for processing.

Description of the Material. The properties of the Lake Manyara and Sumbawanga emeralds are, for the most part, consistent with those of emeralds from other biotite schist localities, especially those from the Ural Mountains. In both cases, the crystals are usually heavily included or, more accurately, fractured. Some of the material from Lake Manyara is facetable (figure 26); virtually all of the Sumbawanga material (being of a "milky" nature) is suitable only for carving or cutting into cabochons (Themelis, 1989).

\section{OTHER GEMS IN TANZANIA}

Most gemologists are unaware of the vast majority of Tanzania's gems. In addition to those discussed above, the list of gem materials that have been found in Tanzania includes actinolite, alexandrite, almandine,

Figure 26. Emeralds like this 1.90-ct. pear shape have been mined from the Lake Manyara region of Tanzania for many years. Photo (C) GIA and Tino Hammid.

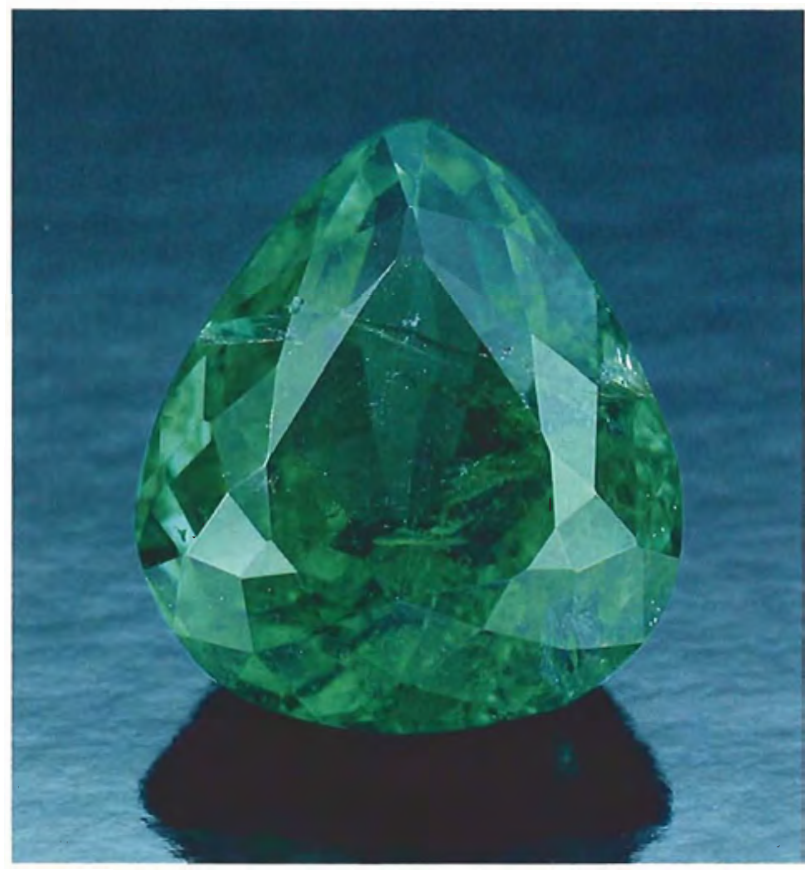




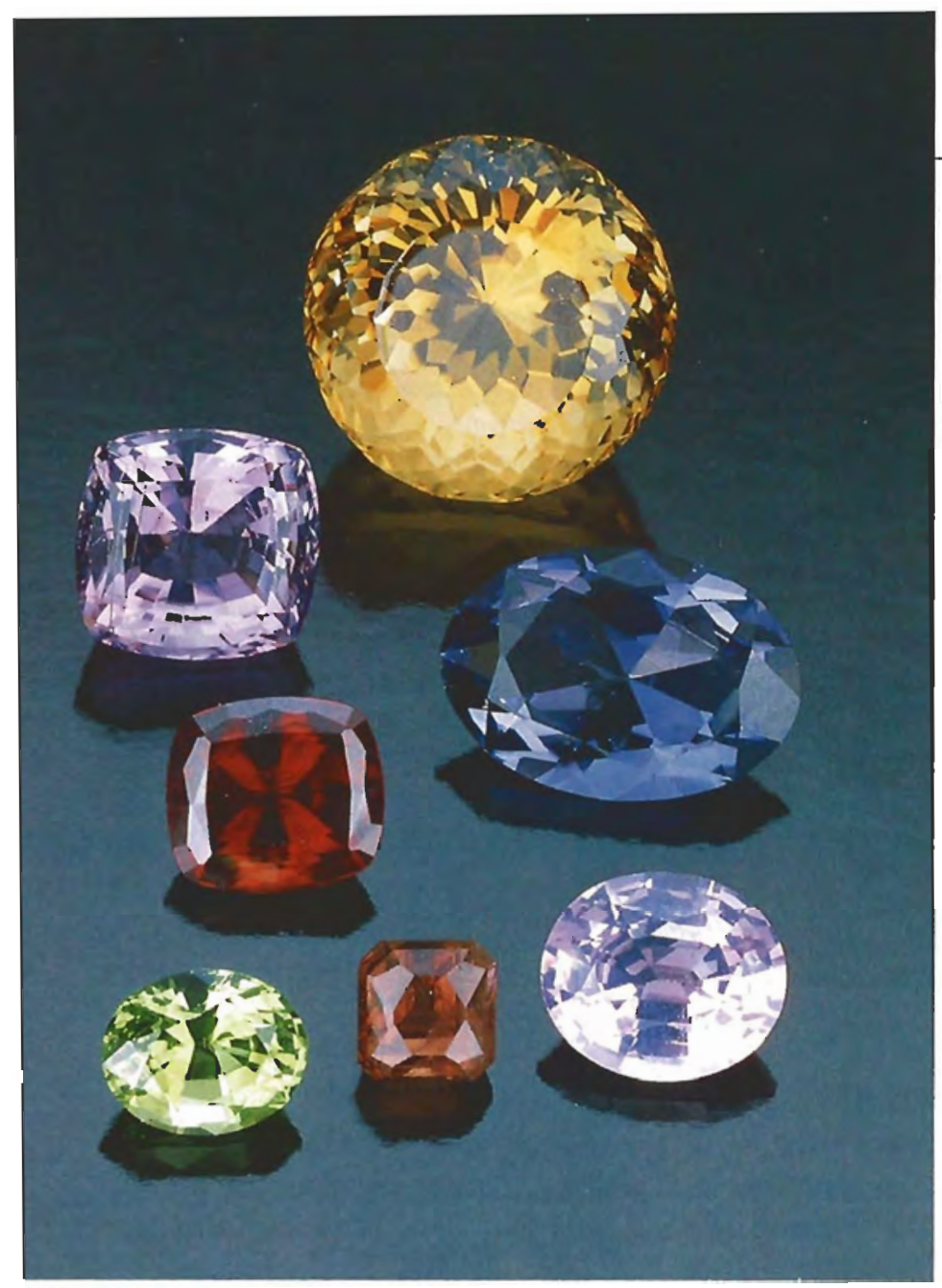

Figure 27. Tanzania is especially rich in its variety of gems. Shown here are a 12.62-ct golden scapolite, a 3.63-ct purple scapolite, a 3.48-ct iolite, a 1.80-ct zircon, a 2.15-ct spinel, a 1.29-ct alexandrite chrysoberyl, and a 1.39-ct peridot. Photo (C) GIA and Tino Hammid.

amblygonite, amethyst, andalusite, apatite, aquamarine, bronzite, cat's-eye chrysoberyl, chrysoprase, cryptocrystalline quartz, diopside, enstatite, epidote, euclase, feldspar (moonstone), fluorite, hypersthene, idocrase, iolite, kornerupine, kyanite, malachite, pearls, peridot, phenakite, prase opal, rock crystal quartz, rhodonite, scapolite, sillimanite, sinhalite, sphene, spinel, topaz, turquoise, and zircon /see, e.g., figure 27). The following briefly describes the occurrences of some of these other gemstones in Tanzania.

Alexandrite. The change-of-color variety of chrysoberyl, alexandrite, occurs in association with the emerald deposits at Lake Manyara. They are found in what Dr. E. Gübelin has described as "actinolite schists" of metamorphic origin.

Lake Manyara alexandrites exhibit a distinct change of color from bluish green in day or fluorescent light to purplish red in incandescent light. Densely packed actinolite fibers produce chatoyancy in some of the material. Unlike other natural alexandrites, which are inert to ultraviolet radiation, Lake Manyara alexandrites fluoresce a strong to medium dull red to long-wave U.V., and may fluoresce a weak yellow to short-wave U.V. (Gübelin, 1976).

Amethyst. Purple quartz appears in the early geologic literature of Tanzania. It is one of the more abundant gemstones, with over 12 occurrences recorded. It has been found within an area from just southeast of Lake Victoria in the northwest part of the country to Korogwe in the northeast to Morogoro just west of Dar es Salaam.

Scapolite. The major locality for golden yellow and purple scapolite is in the Mpwapwa region near Dodoma. Many kilograms of yellow crystals, usually $2-5 \mathrm{~cm}$ long, have appeared on the market in recent years. Yellow cat's-eye scapolite has also been found at Mpwapwa. In addition, some yellow scapolite is recovered at Umba (Solesbury, 1967; Zwaan, 1971). Considerable research has been done on the gemological properties and chemical composition of this complex gem mineral (Graziani et al., 1983).

Spinel. Fine spinels have been discovered with rubies in the Morogoro region, particularly at the Matombo mine (Hänni and Schmetzer, 1991). Spinels in a variety of unusual colors were shown at the 1992 Tucson Gem and Mineral shows. They were reported as coming from the Umba Valley (Koivula and Kammerling, 1991al.

Zircon. Tanzanian zircon in a variety of colors has appeared at the Tucson Gem and Mineral shows since the late 1980s (Koivula and Kammerling, 1990). Keller (in press) names Mavumbi and Handeni, in the Tanga province, as localities. Zircon is also found in the Umba area. Experiments by one of the authors $(A B)$ revealed that dark purple zircon, on heating, turns bright yellow.

\section{CONCLUSION}

The complex geologic environment of East Africa has resulted in an unparalleled diversity of gem materials in an equally diverse range of colors, dramatically illustrated by the gem riches of Tanzania. Production of diamonds, rubies, sapphires, tanzanites, and garnets is already significant and promises to increase. 
There is considerable potential for other gem materials such as tourmaline, emerald, aquamarine, alexandrite, amethyst, peridot, scapolite, spinel, and zircon. Perhaps a virtually unknown stone, such as vanadium diopside, will emerge from Tanzania as a major gem material, as tanzanite and tsavorite have done.

Tanzania's ultimate success as a gem-producing nation, however, depends as much on international cooperation and economic support as it does on its gem resources. Now that the Tanzanian government is actively promoting its gem resources to the international community, the promise may become fulfilled. Under the auspices of the Ministry of Water,
Energy, and Minerals, on May 26 and 27, 1992, the Tanzanian Miners' and Dealers' Association (TAMIDA) held its first gem auction since the early 1980 s. More than 60 miners and dealers, including buyers from more than a dozen countries worldwide, participated in the sale at Arusha of more than a ton of ruby, sapphire, tsavorite, tanzanite, rhodolite, and other gem materials (C. Bridges and A. Suleman, pers. comms., 1992). A second auction is scheduled for October 1992, apparently signaling that Tanzania will continue its open-door policy in the future-a promising sign for the international gemological community.

\section{REFERENCES}

Anderson B. W. (1968) Three items of interest to gemmologists. Journal of Gemmology, Vol. 11, No. 1, pp. 1-3.

Background analysis-Tanzania: A small diamond producer with little prospects (1986). Diamond Intelligence Briefs, Vol. 2, No. 34, p. 211 .

Balfour I. (1987) Famous Diamonds. Collins, London.

Bank H. (1968) Tansanit-Neue Varietatsbezeichnung fur strontiumhalltigen trichroitischen Zoisit. Gold el Silber-Uhren + Schmuck, No. 11, p. 66.

Bank H. (1970) Hochlichtbrechender Orangefarbiger Korund aus Tansania. Zeitschrift der Deutschen Gemmologischen Gesellschaft, Vol. 19, No. 1, pp. 1-3.

Bank H. (1982) Tourmalines from East Africa. Gold e SilberUhren + Schmuck, No. 3, pp. 140-141.

Bank H., Berdesinski W., Ottemann J. (1970) Durchsichtiger smaragtgrüner Grossular aus Tansania. Zeitschrift der Deutschen Gemmologischen Gesellschaft, Vol, 19, No. 1, pp. 4-7.

Bank H., Henn U. (1988) Changierende chromhaltige Turmaline von Ostafrika. Zeitschrift der Deutschen Gemmologischen Gesellschaft, Vol. 36, No. 3-4, pp. 161-163.

Barot N.R., Boehm E. (1992) Gem-quality green zoisite. Gems e) Gemology, Vol. 28, No. 1, pp. 4-15.

Bassett H. (1956) A geological reconnaissance into the Umba Steppe region of Tanga Province, Tanganyika and a visit to Mrima Hill in Kenya, 1953. Geological Survey of Tanganyika, Report No. HB/2, Government Printing Office, Dar es Salaam, Tanganyika.

Bills J.H., Martineau M.P., Park J.G. (1991) Artisanal mining in the Lake Victoria Goldfields, Tanzania. In African Mining '91, Elsevier Scientific, London, pp. 291-296.

Bridges C.R. (1974) Green grossularite garnets ("tsavorites") in East Africa. Gems (1) Gemology, Vol. 14, No. 10, pp. 290-295.

Bridges C.R. (1982) Gemstones of East Africa. In D. M. Eash, Ed., International Gemological Symposium Proceedings, Gemological Institute of America, Santa Monica, CA, pp. 263-275.

Bridges C.R. (1987) Tsavorite. Jewelers' Quarterly, Annual Color Pages, pp. 49-51.

Crowningshield G.R. (1970) A rare alexandrite garnet from Tanzania. Gems \&) Gemology, Vol. 13, No. 6, pp. 174-177.

Crowningshield G.R. (1983) Padparadscha: What's in a name? Gems \& Gemology, Vol. 19, No. 1, pp. 30-36.

Curtis C.M. (1980) "Malaya," lady of the evening. Lapidary Journal, Vol. 33, No. 11, pp. 2348-2349.

Dietrich R.V. (1985) The Tourmaline Group. Van Nostrand Reinhold, New York.
Federman D. (1991) Gem profile: Tanzanite, mainstream bound. Modern Jeweler, Vol. 90, No. 6, pp. 37-38.

Gobba J.M. (1991) The geology and mineralogy of some kimberlites in the Mwadui area. In Fifth International Kimberlite Conference, Araxa, June 1991, Extended Abstracts, CPRM-Special Publication 2/91, Brasilia, Brazil, pp. 116-118.

Graziani G., Gübelin E., Lucchesi S. (1983) Observations on some scapolites of central Tanzania. Further investigations. Journal of Gemmology, Vol. 18, No. 5, pp. 379-381.

Griffin W.L., Ryan C.G., O'Reilly S.Y., Nixon P.H., Win T.T. (1991) Trace elements in garnets from Tanzanian kimberlites: Relation to diamond content and tectonic setting. In Fifth International Kimberlite Conference, Araxa, June 1991, Extended Abstracts, CPRM-Special Publication 2/91, Brasilia, Brazil, pp. 145-147.

Gübelin E.J. (1969) Anyolite clarification. Australian Gemmologist, Vol. 10, No. 5, pp. 28-29.

Gübelin E.J. (1974) The emerald deposit at Lake Manyara, Tanzania. Lapidary Joumal, Vol. 28, No. 2, pp. 338-360.

Gübelin E.J. (1976) Alexandrite from Lake Manyara, Tanzania. Gems \&) Gemology, Vol. 15, No. 7, pp. 203-209.

Hänni H.A., Schmetzer K. (1991) New rubies from the Morogoro area, Tanzania. Gems e) Gemology, Vol. 27, No. 3, pp. 156-167.

Henn U., Bank H. (1991) Rubies of facet-cutting quality from Tanzania. Goldschmiede und Uhrmacher Zeitung, Vol. 89, No. 6, p. 116.

Henn U., Bank H. (1992) On the distinction between yellow corundum/"padparadschas"/rubies. Part I. Goldschmiede und Uhrmacher Zeitung, Vol. 90, No. 3, p. 226.

Herschede M.P. (1986) Chrome tourmaline from East Africa, Jewelers' Quarterly, First Quarter, pp. 6, 7, 30.

Horton M. (1987) The Swahili corridor. Scientific American, Vol. 257, No. 3, pp. 86-93.

Hughes R.W. (1990) Corundum. Butterworth-Heinemann, London.

Hurlbut C.S. (1969) Gem zoisite from Tanzania. American Mineralogist, Vol. 54, No. 5/6, pp. 702-709.

ICA presents 1991 world mining report (1991). Colored Stone, Vol. 4, No. 4, pp. 19-23.

Janse A.J.A. (1991) Is Cliffords Rule still valid? Affirmative examples from around the world. Fifth International Kimberlite Conference, Araxa, June 1991, Extended Abstracts, CPRMSpecial Publication 2/91, Brasilia, Brazil, pp. 196-198.

Janse A.J.A. (1992) Diamond sources in Africa. In A. S. Keller, Ed. Proceedings of the International Gemological Symposium 
1991, Gemological Institute of America, Santa Monica, CA, p. 55.

Jobbins E.A., Saul J.M., Statham P.M., Young B.R. (1978) Studies of a gem garnet suite from the Umba River, Tanzania. Journal of Genmology, Vol. 16, No. 3, pp. 161-171.

Jourdan P. (1991) Regional strategies for the minerals industries of the States of the SADCC. In African Mining '91, Elsevier Scientific, London, pp. 347-353.

Kane R.E., Kampf A.R., Krupp H. (1990) Well-formed tsavorite gem crystals from Tanzania. Gems $\Theta$ Gemology, Vol. 26, No. 2, pp. 142-148.

Keller P. (in press) Gems of East Africa, Geoscience Press, Phoenix, $\mathrm{AZ}$.

Key R.M., Hill P.G. (1989) Further evidence for the controls on the growth of vanadium grossular gamets in Kenya. Joumal of Gemmology, Vol. 21, No. 7, pp. 412-422.

Key R.M., Ochieng I.O. (1991al Ruby and gamet gemstone deposits in S.E. Kenya: Their genesis and recommendations for exploration. In African Mining '91, Elsevier Scientific, London, pp. 212-127.

Key R.M., Ochieng J.O. (1991b) The growth of rubies in southeast Kenya. Journal of Gemmology, Vol. 22, No. 8, pp. $484-496$.

Kirkley M.B., Gurney J.J., Levinson A.A. (1991) Age, origin, and emplacement of diamonds: Scientific advances of the last decade. Gems \&) Gemology, Vol. 27, No. 1, pp. 2-25.

Koivula J.I., Kammerling R.C. (1988) Gem news: Change-of-color garnets. Gems et) Gemology, Vol. 24, No. 3, pp. 176-177.

Koivula J.I., Kammerling R.C. (1989) Gem news: Star rhodolite gamet. Gems et) Gemology, Vol. 25, No. 1, pp. 48-49.

Koivula J.I., Kammerling R.C. (1990) Gem news: Tanzanian zircon. Gems e) Gemology, Vol. 26, No. 1, pp. 103-104.

Koivula J.I, Kammerling R.C. (1991a) Gem news: Tanzanian spinel. Gems $\Leftrightarrow$ Gemology, Vol. 27, No. 3, p. 183

Koivula J.I., Kammerling R.C. (1991b) Gem news: Unusual red zoisite. Gems e) Gemology, Vol. 27, No. 3, pp. 185-186.

Koivula J.I., Kammerling R.C. (1991c) Gem news: Update on Tanzanian mining. Gems et) Gemology, Vol. 27, No. 4, p. 262.

Malisa E. (1987) Geology of the tanzanite gemstone deposits in the Lelatema area, northest Tanzania (Ph.D. Thesis). Annales Academiae Scientiarum Fennicae 111, Geologica Geographica, Vol. 146, pp. 1-160.

Malisa E., Muhongo S. (1990) Tectonic setting of gemstone mineralization in Proterozoic metamorphic terrane of the Mozambique belt in Tanzania. Precambrian Research (III), Vol. 46, No. 1-2, pp. 167-176.

Manson D.V., Stockton C.M. (1984) Pyrope-spessartine garnets with unusual color behavior. Gems ef Gemology, Vol. 20, No. 4, pp. 200-207.

Msolo A.P.B. (1992) Ruby mining in the Morogoro region. SMI (Small Mining International) Bulletin, No. 4, p. 7.

Muije P., Muije C.S., Muije L.E. (1979) Colorless and green grossularite from Tanzania, Gems \&) Gemology, Vol. 16, No. 6, pp. $162-173$

Ngunangwa F.E. (1982) Potential of small-scale mining in Tanzania. In J.M. Neilson, Ed., The Geosciences in International Development, AGID Report No. 8: Strategies for Small-Scale Mining and Mineral Industries, Association of Geoscientists for Intemational Development, Bangkok, pp. 55-61.

Notholt A. (1990) Tanzania: Mineral development. Mining Annual Review, pp. 124-125.

Pohl W., Horkel A. (1980) Notes on the geology and mineral resources of the Mtito Andei-Taita area (Southern Kenyal. Mitteilungen der Osterreichichen Geologischen Gesellschaft, Vol. 73, pp. 135-152.

Pough F.H. (1971) Meet Tanzania's fancy sapphires. Jewelers' Circular-Keystone, Vol. 142, No. 1, pp. 84-100.

Rwezaura M. (1990) Known gemstone deposits in Tanzania. Unpublished manuscript, $27 \mathrm{pp}$.
Sarofim E. (1970) Gem rich Tanzania. Lapidary Journal, Vol. 24, No. $3, \mathrm{pp} .434-441$.

Saul I.M. (1970) Gemstone localities of Tanzania (map). Rockland International Corp., Nairobi, Kenya.

Schmetzer K. (1978) Vanadium ШI als Farbtrager bei natürlichen Silikaten und Oxiden-ein Beitrag zur Kristallchemie des Vanadiums. Ph.D. Dissertation, Heidelberg, Germany.

Schmetzer K. (1986) Natürliche und synthetische RubineEigenschaaften und Bestimmung. Schweizerbartsche, Stuttgart, Germany.

Schmetzer K., Bank H. (1979) Bluish-green zoisite from Merelani, Tanzania. Journal of Gemmology, Vol. I6, No. 8, pp. 5I2-513.

Schmetzer K., Bank H. (1981) Gamets from Umba Valley, Tanzania-members of the solid solution series pyrope-spessartine. Neues Jahrbuch für Mineralogie Monatshefte, No. 8, pp. 349-354.

Schmetzer K., Hänni H.A. (1992) Dyed natural corundum as a ruby imitation. Gems e Gemology, Vol. 28, No. 2, pp. $112-115$.

Solesbury F.W. (1967) Gem corundum pegmatites in NE Tanganyilka. Economic Geology, Vol. 62, No. 7, pp. 983-991.

Stockton C.M., Manson D.V. (1982) Gem gamets: The orange to red-orange color range. In D. M. Eash, Ed., International Gemological Symposium Proceedings, Gemological Institute of America, Santa Monica, CA, pp. 237-242.

Stockton C.M., Manson D.V. (1985) A proposed new classification for gem-quality garnets. Gems e) Gemology, Vol. 21, No. 4, pp. 205-218.

Tanzania known mineral occurrences (map, 1982). Ministry of Mines, Dar es Salaam, Tanzania.

Tanzania signs major diamond deal (1992). Diamond Intelligence Briefs, Vol. 7, No. 143, p. 857.

Tanzania's latent opportunities (1992). Mining Journal, Vol. 318, No. 8164 , pp. 186-187.

Thai joint venture gets Umba exclusive (1989). Colored Stone, Vol. 2, No. 4, p. 25.

Themelis T. (1989) New East African deposits. Lapidary Journal, Vol. 42, No. 11, pp, 34-39.

Tiffany discloses finding what may be a new gem (1968). Wall Street Journal, October 14, p. 4.

Tsai H.M., Meyer H.O.A., Moreau J., Milledge H.J. (1979) Mineral inclusions in diamond: Premier, Jagersfontein and Finsch kimberlites, South Africa, and Williamson Mine, Tanzania. In F. R. Boyd and H. O. A. Meyer, Eds., Kimberlites, Dicltremes, and Diamonds: Their Geology, Petrology, and Geochemistry. Proceedings of the Second International Kimberlite Conference, Vol. 1, American Geophysical Union, Washington, DC, pp. 16-26.

Vidal-Naquet P. (1987) The Harper Atlas of World History. Harper \& Row, New York.

Ward F. (1991) Rubies and sapphires. National Geographic, Vol. 180, No. 4, pp. 100-125.

Webster R. (1961a) Tanganyika tourmalines. The Gemmologist, Vol. 30, No. 356, pp. $41-45$.

Webster R. 1961 b] Corundum in Tanganyika. Gems \&) Gemology, Vol, 10, No. 7, pp. 202-205.

Webster R. (1983) Gems: Their Sources, Descriptions and Identification, 4th ed. Rev. by B. W. Anderson, Butterworth and Co., London.

Wilson A.N., Ed. (1971) Tanzania: Thirty years in production. International Diamond Annual, Vol. 1, p. 71.

Winchell A.N. (1937) Elements of Optical Mineralogy, Part I, 5th ed. John Wiley \& Sons, New York.

Zwaan P.C. (1971) Yellow scapolite: Another gem mineral from Umba, Tanzania. Journal of Gemmology, Vol. 12, No. 7, pp. 304-309.

Zwaan P.C. (1974) Garnet, corundum and other gem minerals from Umba, Tanzania. Scripta Geologica, Vol. 20, pp. 1-41. 